\title{
8-Prenylgenistein, a prenylated genistein derivative, exerted tissue selective osteoprotective effects in ovariectomized mice
}

\author{
Yan Zhang ${ }^{1,2,3}$, Li-Ping Zhou ${ }^{4}$, Xiao-Li Li ${ }^{5}$, Yong-Jian Zhao ${ }^{1,3}$, Ming-Xian Ho ${ }^{4}$, Zuo- \\ Cheng Qiu ${ }^{6}$, Dong-Feng Zhao ${ }^{1,3}$, Daniel Kam-Wah Mok ${ }^{4}$, Qi Shi ${ }^{1,3}$, Yong-Jun Wang ${ }^{1,3,7}$ \\ and Man-Sau Wong ${ }^{2,4}$ \\ ${ }^{1}$ Spine Research Institute, Longhua Hospital, Shanghai University of Traditional Chinese Medicine, Shanghai, PRC \\ ${ }^{2}$ State Key Laboratory of Chinese Medicine and Molecular Pharmacology (Incubation), The Hong Kong Polytechnic University \\ Shenzhen Research Institute, Shenzhen, PRC \\ ${ }^{3}$ Key Laboratory of Theory and Therapy of Muscles and Bones of Ministry of Education, Shanghai, PRC \\ ${ }^{4}$ Department of Applied Biology and Chemical Technology, The Hong Kong Polytechnic University, Hung Hom, Kowloon, Hong \\ Kong, PRC \\ ${ }^{5}$ School of Medical Instrument and Food Engineering, University of Shanghai for Science and Technology, Shanghai, PRC \\ ${ }^{6}$ Institute of Traditional Chinese Medicine and Natural Products, College of Pharmacy, Jinan University, Guangzhou, PRC \\ ${ }^{7}$ School of Rehabilitation Science, Shanghai University of Traditional Chinese Medicine, Shanghai, PRC \\ Correspondence to: Man-Sau Wong, email: man-sau.wong@polyu.edu.hk \\ Yong-Jun Wang, email: yjwang8888@126.com
}

Keywords: genistein; 8-prenylgenistein; bone; estrogenic effects; uterus

Received: June 03, 2017 Accepted: September 23, 2017 Epub: March 19, 2018 Published: May 11, 2018

Copyright: Zhang et al. This is an open-access article distributed under the terms of the Creative Commons Attribution License 3.0 (CC BY 3.0), which permits unrestricted use, distribution, and reproduction in any medium, provided the original author and source are credited.

\section{ABSTRACT}

Our previous study reported that the in vitro osteogenic effects of 8-prenylgenistein (8PG) were more potent than its parent compound genistein. This study aimed to evaluate the osteoprotective effects of 8PG in ovariectomized (OVX) mice as well as to characterize its estrogenic effects in uterus. Mature OVX mice were treated with phytoestrogen-free diet containing 8PG or genistein. Trabecular bone mass and most of the micro-structural parameters were ameliorated at the distal femoral metaphysis in OVX mice upon treatment with genistein and both doses of 8PG. The beneficial effects of 8PG on trabecular bone were confirmed by safranin $O$ and ABHO staining. 8PG markedly inhibited the ovariectomy-induced mRNA expressions of RANKL/OPG, ALP, COL, OCN, cathepsin K and ER-a in bone. In contrast, genistein further increased the ovariectomy-induced ER-a expression in bone. The uterus index was increased in genistein-treated group. Genistein up-regulated the expression of ER-a and PR, while 8PG significantly down-regulated the ER-a and C3 expression in uterus of OVX mice. Moreover, genistein, but not 8PG, increased expressions of ERa, PCNA and C3 in Ishikawa cell. This study suggested that 8PG improved trabecular bone properties in OVX mice without exerting uterotrophic effects and its estrogenic actions were distinct from those of genistein.

\section{INTRODUCTION}

Soybean-based foods have been regarded as healthy food choices as a result of the evidence generated from epidemiological studies that populations consuming large amounts of soybeans have a lower risk of developing chronic diseases, notably osteoporosis $[1,2]$. Soy foods contain an array of biologically-active phytochemicals that may confer important health benefits
[3]. These compounds include the isoflavones, so-called phytoestrogens, which have received considerable attention because of their estrogen-like properties in certain tissues, including bone [4-6]. However, as the in vivo effects of phytoestrogens are similar to estrogens and their actions are mediated through estrogen receptors (ER- $\alpha$ and ER- $\beta$ ), concerns for the safety of using phytoestrogens amongst medical scientists are increasing $[7,8]$. These concerns have led to the clinical studies that 
evaluate the safety of soy isoflavones on reproductive organs in postmenopausal women [8] and infants [9]. Thus, the major focus of phytoestrogens research and bone health is to identify novel estrogenic compounds that exhibit tissue selectivity in reducing menopausal related bone loss without inducing undesirable stimulatory effects in reproductive tissues.

Prenylated flavanones, a unique class of naturally occurring flavonoids, are characterized by the presence of a prenylated side chain in the flavonoid skeleton [10]. This class of compound has recently attracted much attention due to their exhibition of a wide range of interesting pharmacological properties, including estrogenic, anti-inflammatory, anti-viral and antioxidative effects, especially their superior activities over those of its parent compound [11]. Emerging evidences showed that the prenylation at different sites produces differential biological responses [11-13] and the presence of 8-prenylation increased the bioactivities of the parent flavonoid compounds, such as 8-prenylnaringenin (8PN) $[14,15]$ and 8-prenylapigenin [16]. As compared to naringenin, $8 \mathrm{PN}$ led to a strong increase in estrogenicity as observed in the abilities to induce transactivation activities of the yeast screen estrogen receptor assay, stably transfected luciferase reporter activities in MVLN cells derived from human breast cancer cells and alkaline phosphatase (ALP) activities of Ishikawa cells [17]. In addition, the estrogenic activities of $8 \mathrm{PN}$ in vitro, including the ability to induce estrogen responsive reporter activities in yeast and ALP activities in Ishikawa cells, were greater than those of the established phytoestrogens such as coumestrol, genistein and daidzein, and its high estrogenic activity was confirmed in vivo as demonstrated by the induction of uterine vascular permeability in mice in response to subcutaneously administration of 8PN [18].

The altered estrogenicity induced by the modification of prenylation appears to play a significant role in contributing to the actions of different flavonoid compounds on bone metabolism. The existence of a prenyl group on $\mathrm{C}-8$ position of icariin has been suggested to be the reason why icariin is more potent than genistein in osteogenic activity [19]. Moreover, the prenyl group on 8PN was also found to play a significant role in contributing to its activities in enhancing bone formation and inhibiting bone resorption in vitro $[15,20]$. Indeed, $8 \mathrm{PN}$ has a more pronounced ability than naringenin in enhancing osteoblast differentiation and mineralization [21]. Our group previously studied the structure-activity relationship of genistein (Figure 1) with prenylation at different position and found that the prenylation at position C-8 of ring A, namely 8-prenylgenistein (8PG, Figure 1), displayed higher potency in stimulating the proliferation, differentiation and mineralization of osteoblasts [22, 23]. The results revealed that $8 \mathrm{PG}$ might be the bioactive compound in Erythrina variegata L. (EV) that accounted for the bone protective actions in ovariectomy-induced osteoporotic rats [24] and mice [25]. These studies clearly indicated that the prenylation at $\mathrm{C}-8$ position of flavonoid compound is important for inducing osteogenesis. However, the in vivo osteoprotective efficacy of $8 \mathrm{PG}$ is yet to be determined.

With the discovery of multiple ERs that can mediate the effects of estrogen and the complexity of estrogen signaling, concerns are raised about the selectivity of different endocrine disrupting chemicals (including phytoestrogens) towards estrogen sensitive tissues [26]. It is important to understand how tissue selectivity of estrogenic compounds can be achieved. Thus, to assess the risks and benefits of using $8 \mathrm{PG}$ for the management of postmenopausal osteoporosis, the evaluation on its tissue selectivity as well as the elucidation of its molecular actions is warranted. The present study was performed to evaluate the estrogenic effects of $8 \mathrm{PG}$ in bone and uterus using ovariectomized mice as in vivo model and osteoblastic (MG-63 and MC3T3-E1) cells and human endometrial (Ishikawa) cells as in vitro model.

\section{RESULTS}

\section{Body weight and biochemistries in serum and urine}

The effects of genistein and 8PG at low and high dose on serum and urine chemistries and body weight were shown in Table 1. Ovariectomy induced the increase of body weight in mice $(P<0.01$, vs Sham $)$, and treatment with genistein or $8 \mathrm{PG}$ did not affect body weight of OVX mice. Urinary $\mathrm{Ca}$ and $\mathrm{P}$ levels were significantly increased in mice in response to ovariectomy $(P<0.05$, vs Sham). Urinary Ca level was significantly reduced by $62 \%$ in OVX mice treated with high dose of $8 \mathrm{PG}$ $(P<0.05$, vs OVX). Serum OCN (a bone formation marker, $P<0.05$ ) and OPN (a bone resorption marker, $P<0.001)$ levels in OVX group were both increased as compared to those in Sham group, indicating an increase in bone turnover in mice induced by ovariectomy. Genistein and 8PG failed to alter the level of serum OCN in OVX mice. In contrast, both genistein $(P<0.05)$ and 8PG $(P<0.001)$ significantly decreased serum OPN level, which was not statistically different between high dose of 8PG group and Sham group.

\section{Micro CT analysis}

The effects of 8PG as compared to genistein on trabecular bone properties of OVX mice were determined at the distal end of femur and the proximal metaphysis of tibia. The profiles of 3D images clearly demonstrated the loss of trabecular bone mass and trabecular bone number as well as the deterioration of cancellous bone structure at the distal end of femur (Figure 2A) and the proximal metaphysis of tibia (Figure 2B) in OVX mice. 
Table 1: Body weight, uterus index and chemistries in serum and urine

\begin{tabular}{|c|c|c|c|c|c|}
\hline & Sham & OVX & Gen & 8PG-L & 8PG-H \\
\hline $\begin{array}{l}\text { Body weight } \\
\text { (g) }\end{array}$ & $22.1 \pm 0.5$ & $24.2 \pm 0.3^{\# \#}$ & $23.6 \pm 0.3$ & $24.7 \pm 0.4^{\# \#}$ & $24.8 \pm 0.4^{\# \#}$ \\
\hline $\begin{array}{l}\text { Uterus index } \\
(\mathrm{mg} / \mathrm{g})\end{array}$ & $2.61 \pm 0.21$ & $0.47 \pm 0.02^{\# \# \#}$ & $0.64 \pm 0.03^{* * *}$ & $0.46 \pm 0.01^{\# \# \#}$ & $0.48 \pm 0.03^{\# \# \#}$ \\
\hline $\begin{array}{l}\text { Serum Ca } \\
(\mathrm{mg} / \mathrm{dL})\end{array}$ & $11.02 \pm 0.21$ & $10.68 \pm 0.28$ & $10.47 \pm 0.43$ & $11.79 \pm 0.42$ & $11.08 \pm 0.49$ \\
\hline $\begin{array}{l}\text { Serum P } \\
(\mathrm{mg} / \mathrm{dL})\end{array}$ & $6.60 \pm 0.48$ & $6.45 \pm 0.29$ & $7.08 \pm 0.41$ & $6.69 \pm 0.20$ & $7.12 \pm 0.41$ \\
\hline $\begin{array}{l}\text { Serum OCN } \\
(\mathrm{ng} / \mathrm{ml})\end{array}$ & $22.9 \pm 6.6$ & $50.9 \pm 6.6^{\#}$ & $58.5 \pm 8.5^{\# \#}$ & $52.7 \pm 4.2^{\#}$ & 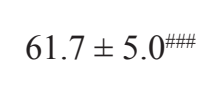 \\
\hline $\begin{array}{l}\text { Serum OPN } \\
(\mathrm{ng} / \mathrm{ml})\end{array}$ & $12.5 \pm 0.6$ & $18.6 \pm 0.5^{\# \# \#}$ & $16.5 \pm 0.7^{\# \# *}$ & $14.9 \pm 0.4^{* * * \#}$ & $13.1 \pm 0.3^{* * *}$ \\
\hline $\begin{array}{l}\text { Urine } \mathrm{Ca} / \mathrm{Cr} \\
(\mathrm{mg} / \mathrm{mg})\end{array}$ & $0.182 \pm 0.053$ & $0.470 \pm 0.121^{\#}$ & $0.213 \pm 0.031$ & $0.221 \pm 0.062$ & $0.180 \pm 0.030^{*}$ \\
\hline $\begin{array}{c}\text { Urine } \mathrm{P} / \mathrm{Cr} \\
(\mathrm{mg} / \mathrm{mg})\end{array}$ & $1.45 \pm 0.25$ & $3.95 \pm 0.37^{\# \#}$ & $4.33 \pm 0.61^{\# \# \#}$ & $3.15 \pm 0.56$ & $3.25 \pm 0.31^{\#}$ \\
\hline
\end{tabular}

Values were expressed as means $\pm \mathrm{SEM}, n=10$ in each group. ${ }^{\#} P<0.05,{ }^{\#} P<0.01,{ }^{\# \#} P<0.001$, vs. Sham group, ${ }^{*} P<0.05$, ${ }^{* * *} P<0.001$, vs. OVX group. Ca, calcium; Cr, creatinine; $\mathrm{P}$, phosphorus; OCN, osteocalcin; OPN, osteopontin.

Such morphological changes for trabecular bone in OVX mice were quantitatively reflected by the micro-CT measurement of bone parameters as shown in Table 2. Ovariectomy significantly induced the decrease in BMD/ TV, Conn.D, BV/TV, Tb.N, and the increase in Tb.Sp at proximal tibial metaphysis (Table 2A) and distal femoral end (Table $2 \mathrm{~B})$ in mice $(P<0.05$, vs Sham).

Genistein appeared to moderately improve the tibial parameters for bone mass and micro-architecture in OVX mice but the changes were not statistically significant (Table 2A). Low dose of 8PG significantly decreased DA $(P<0.05)$, and high dose of $8 \mathrm{PG}$ dramatically increased BMD/TV $(P<0.05)$ and Tb. Th $(P<0.01)$ and decreased DA $(P<0.05)$ and Tb. Sp $(P<0.05)$ of proximal metaphysis of tibia in OVX mice (vs OVX, Table 2A). The effects of genistein and two doses of $8 \mathrm{PG}$ were more prominent at distal metaphysis of femur in OVX mice (Table 2B). All phytoestrogens treatments could significantly increase $\mathrm{BMD} / \mathrm{TV}$ and $\mathrm{BV} / \mathrm{TV}$, and improve trabecular bone architectural parameters including Tb. N and Tb. Sp at distal femur of OVX mice $(P<0.05$, vs OVX).

\section{Bone histomorphology}

To confirm the beneficial effects of $8 \mathrm{PG}$ on trabecular bone, the local histomorphology was performed on proximal tibial metaphysis and distal femoral end<smiles>CC(C)=CCc1c(O)cc(O)c2c(=O)c(-c3ccc(O)cc3)coc12</smiles>

8-prenyl genistein<smiles>O=c1c(-c2ccc(O)cc2)coc2cc(O)cc(O)c12</smiles>

genistein

Figure 1: Chemical structure of genistein and 8-prenylgenistein (8PG). 
(Figure 3). The safranin O staining (Figure 3A) showed the loss and destruction of woven trabecular bone in OVX mice, and the Alcian blue/Hematoxylin \& Orange $\mathrm{G}$ (ABHO) staining (Figure 3B) showed the loss of articular chondrocytes (red circle) at the surface of knee joint and the clefts of articular cartilage (brown arrow) at epiphyseal area of proximal tibial metaphysis in OVX mice as compared to those of Sham rats. Treatment with genistein moderately attenuated the ovariectomy-induced pathological changes of trabecular bone at tibia (Figure $3 \mathrm{~A}$, top panel) and femur (Figure 3A, bottom panel) in OVX mice. Most importantly, 8PG at both doses increased the connection and the amount of trabecular bone at tibia and femur (Figure 3A) as well as increased the number of chondrocytes and recovered the structure of articular cartilage (Figure 3B) at proximal tibial epiphysis in OVX mice.

\section{Expression of key regulators for bone metabolism}

To further elucidate the mechanisms of actions of $8 \mathrm{PG}$ in bone, the mRNA expression of osteoblast-specific genes and the osteoclast-specific gene cathepsin K (CtsK) as well as genes involved in estrogenic signaling like estrogen receptor alpha (ER- $\alpha$ ) and $G$ protein-coupled estrogen receptor (GPER) in distal femur of mice were measured (Figure 4). The mRNA expression of alkaline phosphatase (ALP) (Figure 4B, $P<0.01$ ), type I collagen (COL) (Figure 4B, $P<0.05$ ), osteocalcin (OCN) (Figure $4 \mathrm{~B}, P<0.001)$, the ratio receptor activator of nuclear factor kappa-B ligand (RANKL)/osteoprotegerin (OPG) (Figure 4C, $P<0.05$ ), cathepsin $\mathrm{K}(\mathrm{CtsK})$ (Figure 4C, $P<0.01$ ), and ER- $\alpha$ (Figure 4D, $P<0.001$ ) in femur were increased in mice in response to ovariectomy. The mRNA expression of ALP and OCN and the ratio RANKL/ OPG in mice femur were significantly reduced in either genistein- or 8PG-treated OVX mice $(P<0.05$, vs OVX). In addition, treatment of OVX mice with $8 \mathrm{PG}$ at both doses dramatically reduced the mRNA expression of CtsK $(P<0.01)$ and high dose of 8PG markedly suppressed ovariectomy-induced expression of COL $(P<0.05)$ in femur of OVX mice (vs OVX). In contrast, genistein did not alter CtsK and COL mRNA expression in femur of OVX mice. Most importantly, treatment of OVX mice with genistein further increased the mRNA expression of ER- $\alpha(P<0.05)$ while treatment with 8PG at both doses suppressed ER- $\alpha$ expression induced by ovariectomy

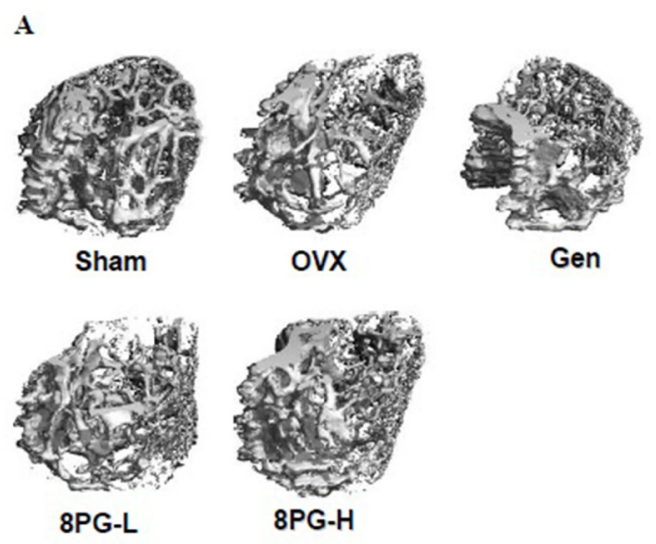

B
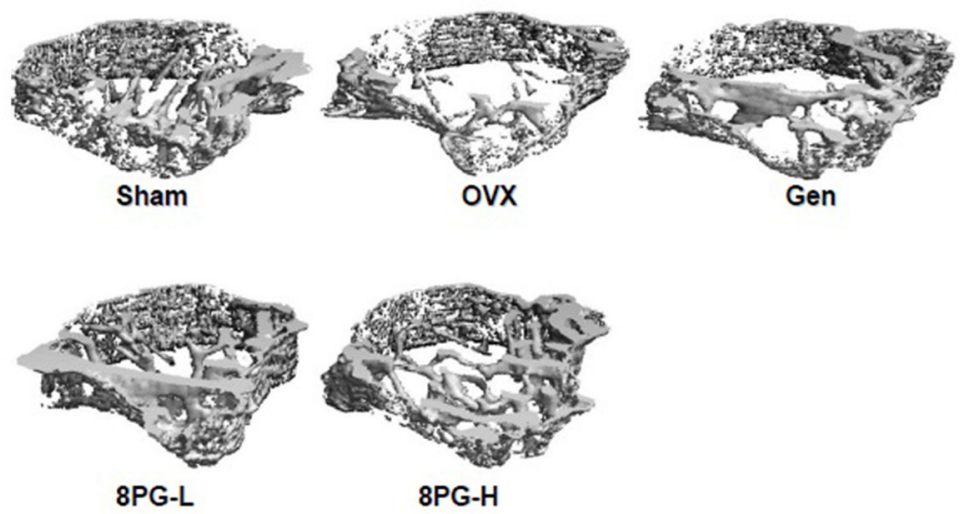

Figure 2: A representative microcomputed tomography 3-dimensional image of the trabecular bone at distal femoral end (A) and at proximal tibial head (B) in Sham mice and OVX mice treated with vehicle (OVX), genistein (Gen) or low (8PG-L) or high (8PG-H) dose of 8-prenylgenistein for 7 weeks. 
Table 2: Effects of 8-prenylgenistein on trabecular bone parameters measured by micro-CT at the proximal metaphysis of tibia (A) and the distal metaphysis of femur (B) in ovariectomized mice

\begin{tabular}{|c|c|c|c|c|c|}
\hline Parameters\Group & Sham & OVX & Gen & 8PG-L & 8PG-H \\
\hline $\begin{array}{c}\mathrm{BMD} / \mathrm{TV} \\
(\mathrm{mg} \mathrm{HA} / \mathrm{ccm})\end{array}$ & $105 \pm 7$ & $59 \pm 3^{\# \#}$ & $67 \pm 9$ & $74 \pm 6$ & $85 \pm 6^{*}$ \\
\hline $\begin{array}{l}\text { Conn.D } \\
\left(1 / \mathrm{mm}^{3}\right)\end{array}$ & $360 \pm 55$ & $136 \pm 31^{\#}$ & $211 \pm 32$ & $197 \pm 15$ & $202 \pm 18$ \\
\hline $\begin{array}{c}\mathrm{BV} / \mathrm{TV} \\
(\%)\end{array}$ & $87.9 \pm 5.9$ & $50.7 \pm 5.7^{\# \#}$ & $67.7 \pm 12.8$ & $71.3 \pm 11.3$ & $77.0 \pm 13.5$ \\
\hline DA & $1.35 \pm 0.04$ & $1.81 \pm 0.03^{\#}$ & $1.60 \pm 0.08$ & $1.34 \pm 0.05^{*}$ & $1.34 \pm 0.03^{*}$ \\
\hline $\begin{array}{c}\text { Tb.N } \\
(1 / \mathrm{mm})\end{array}$ & $2.7 \pm 0.1$ & $1.6 \pm 0.1^{\# \# \#}$ & $1.9 \pm 0.2$ & $1.9 \pm 0.2$ & $1.9 \pm 0.2$ \\
\hline $\begin{array}{l}\text { Tb.Sp } \\
\mu \mathrm{m})\end{array}$ & $337 \pm 17$ & $591 \pm 48^{\# \#}$ & $498 \pm 72$ & $509 \pm 55$ & $439 \pm 43^{*}$ \\
\hline $\begin{array}{l}\text { Tb.Th } \\
(\mu \mathrm{m})\end{array}$ & $33.3 \pm 1.0$ & $30.8 \pm 2.2$ & $33.8 \pm 4.9$ & $36.7 \pm 2.3$ & $39.8 \pm 1.4^{* *}$ \\
\hline
\end{tabular}

B

\begin{tabular}{cccccc}
\hline Parameters\Group & Sham & OVX & Gen & 8PG-L & 8PG-H \\
\hline $\begin{array}{c}\text { BMD/TV } \\
(\mathrm{mg} \mathrm{HA} / \mathrm{ccm})\end{array}$ & $149 \pm 15$ & $97 \pm 7^{\#}$ & $137 \pm 7^{*}$ & $141 \pm 13^{*}$ & $151 \pm 8^{* *}$ \\
$\begin{array}{c}\text { Conn.D } \\
\left(1 / \mathrm{mm}^{3}\right)\end{array}$ & $266 \pm 40$ & $135 \pm 26^{\#}$ & $210 \pm 40$ & $179 \pm 19$ & $192 \pm 22$ \\
$\begin{array}{c}\text { BV/TV } \\
(\%)\end{array}$ & $16.6 \pm 2.1$ & $10.1 \pm 0.6^{\#}$ & $16.8 \pm 0.9^{* *}$ & $15.9 \pm 1.9^{*}$ & $19.7 \pm 1.2^{* *}$ \\
DA & $1.27 \pm 0.02$ & $1.34 \pm 0.10$ & $1.34 \pm 0.05$ & $1.25 \pm 0.03$ & $1.30 \pm 0.07$ \\
$\begin{array}{c}\text { Tb.N } \\
(1 / \mathrm{mm})\end{array}$ & $3.5 \pm 0.2$ & $2.3 \pm 0.1^{\# \#}$ & $3.0 \pm 0.2^{*}$ & $3.1 \pm 0.2^{*}$ & $3.2 \pm 0.2^{*}$ \\
$\begin{array}{c}\text { Tb.Sp } \\
(\mu \mathrm{m})\end{array}$ & $243 \pm 17$ & $385 \pm 13^{\# \# \#}$ & $273 \pm 17^{* *}$ & $295 \pm 27^{*}$ & $257 \pm 24^{* *}$ \\
$\begin{array}{c}\text { Tb.Th } \\
(\mu \mathrm{m})\end{array}$ & $52.3 \pm 2.2$ & $43.5 \pm 2.9^{\#}$ & $54.9 \pm 3.8$ & $59.6 \pm 3.7^{*}$ & $62.4 \pm 0.8^{* *}$ \\
\hline
\end{tabular}

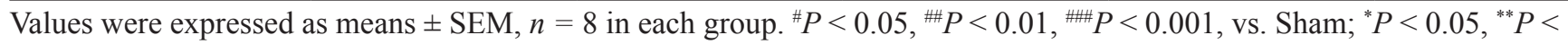
0.01 , vs. OVX. BMD/TV, bone mineral density over total volume; Conn.D, connectivity density; BV/TV, bone volume over total volume; DA, degree of anisotropy; Tb.N, trabecular bone number; Tb.Sp, trabecular bone separation; Tb.Th, trabecular bone thickness.

$(P<0.05)$ in femur (vs OVX). The expression of GPER mRNA in mice femur was not altered in response to ovariectomy and different treatments.

Immunostaining (Figure 4E) showed that ER- $\alpha$ protein expression at distal femoral metaphysis in OVX mice was higher than that in Sham mice, and the treatment with genistein further increased the protein expression of ER- $\alpha$ of OVX mice. While, 8PG treatment at both doses reduced the ER- $\alpha$ expression at the metaphysis of distal femur as compared to that of OVX mice.

\section{Uterus index and estrogen-sensitive target expression}

To evaluate the potential estrogenic effects of $8 \mathrm{PG}$ on uterus in estrogen-deficient mice, the uterus index and the expression of estrogen-targeting genes including ER- $\alpha$, progesterone receptor (PR) and complement component 3 (C3) in uterus were measured. As expected, estrogen deficiency induced by ovariectomy resulted in the atrophy of uterus, as reflected by the significant decrease 
of uterus index in OVX mice (Table 1, $P<0.001$, vs Sham). Treatment of OVX mice with genistein, but not $8 \mathrm{PG}$ at both doses, induced the increase of uterus index $(P<0.001$, vs OVX). Our study also showed that genistein significantly increased the mRNA (Figure 5A) and protein (Figure 5B) expression of PR $(P<0.01)$ in OVX mice and further up-regulated the ovariectomy-induced increase of ER- $\alpha$ protein expression (Figure 5D, $P<0.05$ ) in uterus of OVX mice (vs OVX). In contrast, PR expression and ER- $\alpha$ mRNA expression in uterus were not altered in OVX mice in response to treatment with $8 \mathrm{PG}$ (Figure $5 \mathrm{~A}-$ $5 C)$, while ER- $\alpha$ protein expression in uterus was found to be suppressed in mice in response to $8 \mathrm{PG}$ treatment (Figure 5D, $P<0.05$, vs OVX). In addition, mRNA expression of C3 was significantly decreased in uterus of OVX mice upon treatment with low dose (Figure 5E, $P<$ $0.05)$ and high dose $(P<0.01)$ of 8 PG treatment (vs OVX).

\section{Human endometrial Ishikawa cell}

To determine if $8 \mathrm{PG}$ exert direct estrogenic effects in endometrial cells, its effects on ALP activity, estrogen response element (ERE)-dependent transcriptional activities and ER- $\alpha$ expression in ER positive Ishikawa cells were determined. Moreover, the mRNA expression of $\mathrm{C} 3$ and the protein expression of proliferating cell nuclear antigen (PCNA), reflecting the proliferation of Ishikawa cells, were also measured. Both $8 \mathrm{PG}$ and genistein at the concentration from $10^{-10} \mathrm{M}$ to $10^{-6} \mathrm{M}$ stimulated ALP activity of Ishikawa cells (Figure 6A), and both of them stimulated the ERE activities in Ishikawa cells (Figure $6 \mathrm{~B})$, while, there were poor dose-dependent effects of 8PG and genistein on ALP activity and ERE activity. Genistein significantly increased mRNA (Figure 6C, $P<0.001$ ) and protein (Figure 6D, $P<0.01$ ) expression of ER- $\alpha$ associated with the up-regulation of $\mathrm{C} 3$ mRNA expression (Figure 6C, $P<0.05$ ) and PCNA protein expression (Figure 6D, $P<0.001$ ). The expression of ER- $\alpha, C 3$ and PCNA was not different between $8 \mathrm{PG}$-treated group and control group.

\section{Binding affinity to estrogen receptor}

As shown in Figure 7, increasing concentrations of $17-\beta$ estradiol (E2), genistein and 8 PG decreased specific binding of $\left[{ }^{3} \mathrm{H}\right]$-labeled E2 to recombinant ER- $\alpha$ (A \& C) and ER- $\beta$ (B \& D). The results indicated that $8 \mathrm{PG}$ was a specific ligand to both ER- $\alpha$ and ER- $\beta$. As reported by others [27], the binding affinity of genistein towards ER- $\beta$ (relative binding affinity $(\mathrm{RBA})=58.1 \%$, Figure $7 \mathrm{~B}$ ) was stronger than towards ER- $\alpha(\mathrm{RBA}=0.99 \%$, Figure $7 \mathrm{~A})$. The binding affinity of $8 \mathrm{PG}$ towards ER- $\alpha(\mathrm{RBA}=4.31 \%)$ was comparable to genistein but its binding affinity to ER- $\beta$ $(\mathrm{RBA}=99.6 \%$, Figure 7D) was much higher than genistein .

\section{ERE-luciferase and ALP activities in MG63 cells}

To determine if $8 \mathrm{PG}$ and genistein transcriptionally induce estrogenic responses in bone cells, their abilities to induce ERE-dependent transcriptional activities in human osteosarcoma cell line MG63 cells were determined. MG63 cell transfected with ERE-luciferase construct were treated with vehicle control, genistein and $8 \mathrm{PG}$ at the concentration of $10^{-12} \sim 10^{-6} \mathrm{M}$ (Figure $8 \mathrm{~A}$ ). Genistein and $8 \mathrm{PG}$ at all tested concentrations significantly increased ERE-dependent luciferase activity of MG63 cells. The ERE activities induced by genistein and $8 \mathrm{PG}$ in MG63 cells were comparable at most concentrations
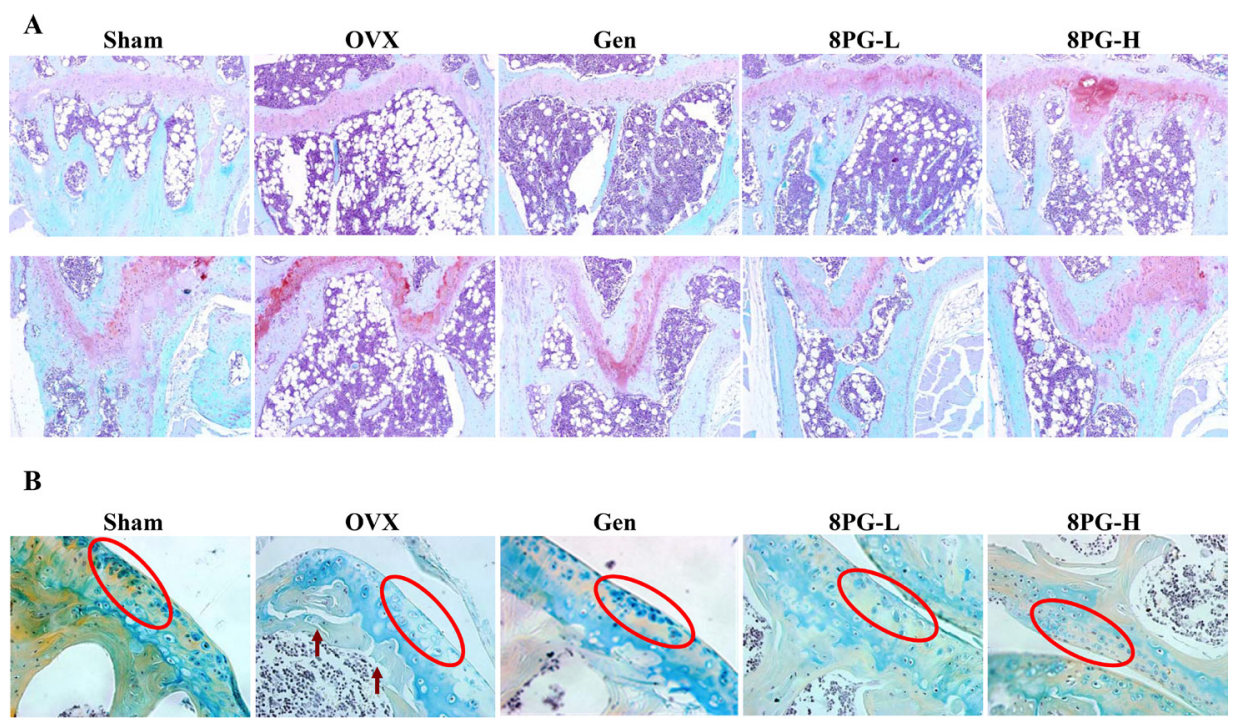

Figure 3: Histological images of proximal tibial metaphysis (A, top panel) and distal femoral metaphysis (A, bottom panel) measured by Safranin O staining (A, Magnification, $\times 100)$ and Alcian blue/Hematoxylin \& Orange G staining $(\mathbf{B}$, Magnification, $\times 400)$ in Sham mice and OVX mice treated with vehicle (OVX), genistein (Gen) or low (8PG-L) or high (8PG-H) dose of 8-prenylgenistein for 7 weeks. Red circle, articular chondrocytes; Brown arrow, cleft of articular cartilage. 
and no statistical difference was found between these treatments. 8PG significantly $(P<0.05)$ enhanced ALP activity of MG63 cells at the concentration of $10^{-12} \sim 10^{-10}$ $\mathrm{M}$, however, genistein at tested concentration $\left(10^{-12} \sim 10^{-6}\right.$ $\mathrm{M})$ did not alter ALP activity of MG63 cells (Figure 8B).

\section{Murine osteoblastic MC3T3-E1 cells}

To further identify if 8-prenylgenistein and genistein differentially regulate the osteoblastic function, the bone nodule formation was determined in murine osteoblastic MC3T3-E1 cells (Figure 8C-8F). Calcium nodule was detected by alizarin red staining in MC3T3-E1 cells upon treatment with $10^{-8} \sim 10^{-5} \mathrm{M}$ of $8 \mathrm{PG}$ and genistein. The most marked effect of $8 \mathrm{PG}$ and genistein on promoting nodule formation was observed at $10^{-6} \mathrm{M}(P<0.001)$ in which more than one fold increase in the amount of
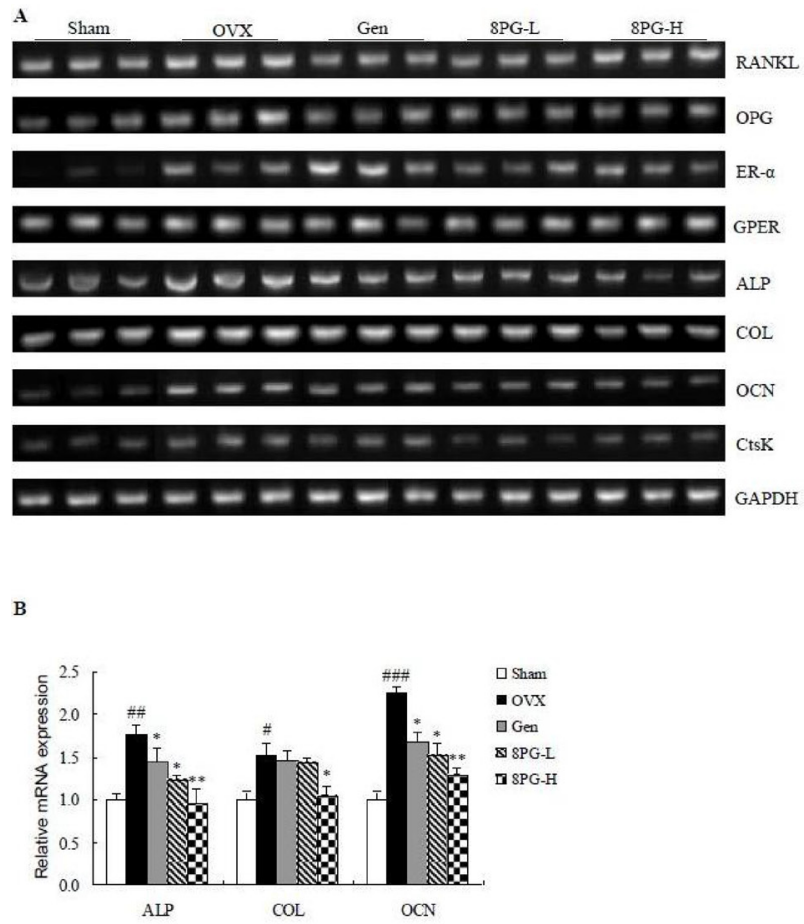

E
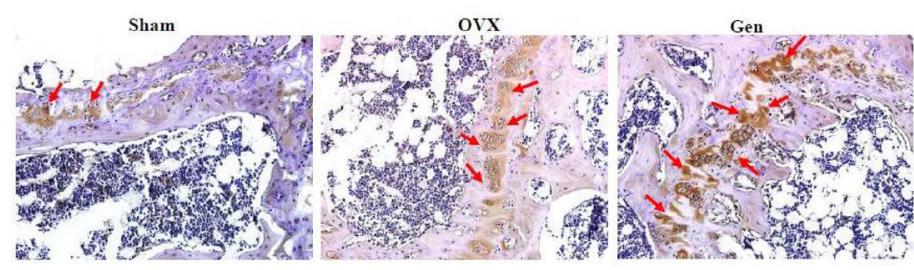

nodule formation were found (vs. vehicle control, Figure $8 \mathrm{D}$ and $8 \mathrm{~F}$ ). While, there was no dose-dependent effect for either $8 \mathrm{PG}$ or genistein under the tested concentration on calcium nodule formation.

\section{DISCUSSION}

Our earlier structure-activity relationship study revealed that 8-prenylgenistein (8PG), a compound with prenylation at site 8 of ring $A$ in parent structure of genistein, was more potent than genistein in increasing osteoblastic functions (proliferation, differentiation and mineralization) in osteoblasts-like cells UMR106 cells [22]. The present study further provided evidences that $8 \mathrm{PG}$ exhibited bone protective effects in ovariectomized (OVX) mice fed with phytoestrogen-free diet. Moreover, unlike genistein, 8PG did not induce uterotrophic effects

C

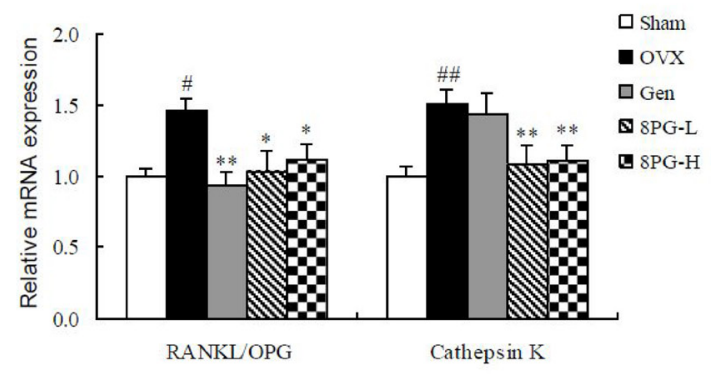

D
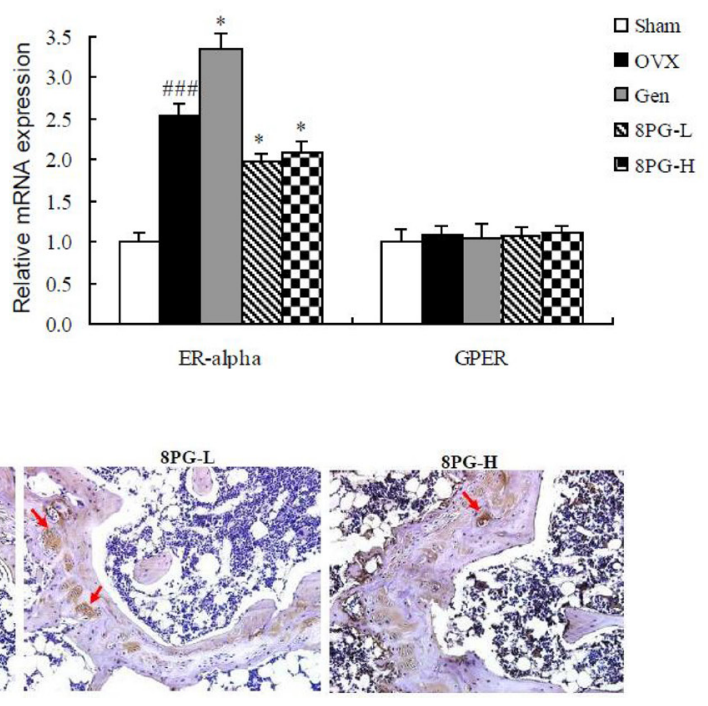

Figure 4: mRNA expression of receptor activator of nuclear factor kappa-B ligand (RANKL), osteoprotegerin (OPG), estrogen receptor alpha (ER- $\alpha)$, G protein-coupled estrogen receptor (GPER), alkaline phosphatase (ALP), type I collagen (COL), osteocalcin (OCN), cathepsin K (CtsK), and protein expression of ER- $\alpha$ in distal femoral end from Sham mice and OVX mice treated with vehicle (OVX), genistein (Gen) or low (8PG-L) or high (8PG-H) dose of 8-prenylgenistein for 7 weeks. (A) Agarose gel electrophoresis. (B-D) the quantitative PCR for the mRNA expression levels, which were expressed as a ratio to the expression of GAPDH. (E) Immunostaining of ER- $\alpha$ expression with positive signal shown by red arrow (Magnification, $\times 200$ ). Values were expressed as means $\pm \mathrm{SEM}, n=8 .{ }^{\#} P<0.05,{ }^{\# \#} P<0.01,{ }^{\# \#} P<0.001$, vs. Sham group; ${ }^{*} P<0.05,{ }^{* *} P$ $<0.01$, vs. OVX group. 
in OVX mice nor change the expression of ER $\alpha$ and proliferating cell nuclear antigen (PCNA) in Ishikawa cells. It is of particular interest to note that the regulation of ER $\alpha$ expression in bone and uterus of OVX mice by 8PG and genistein was different in which 8 PG suppressed and genistein induced its expression in both tissues, suggesting that $8 \mathrm{PG}$ exerted tissue-selective estrogen-like effects in bone, but not uterus, in OVX mice.

Our study clearly demonstrated that 8PG exerted protective effects against bone loss in mice induced by estrogen deficiency. The results also showed that $8 \mathrm{PG}$ dose-dependently suppressed ovariectomy-induced
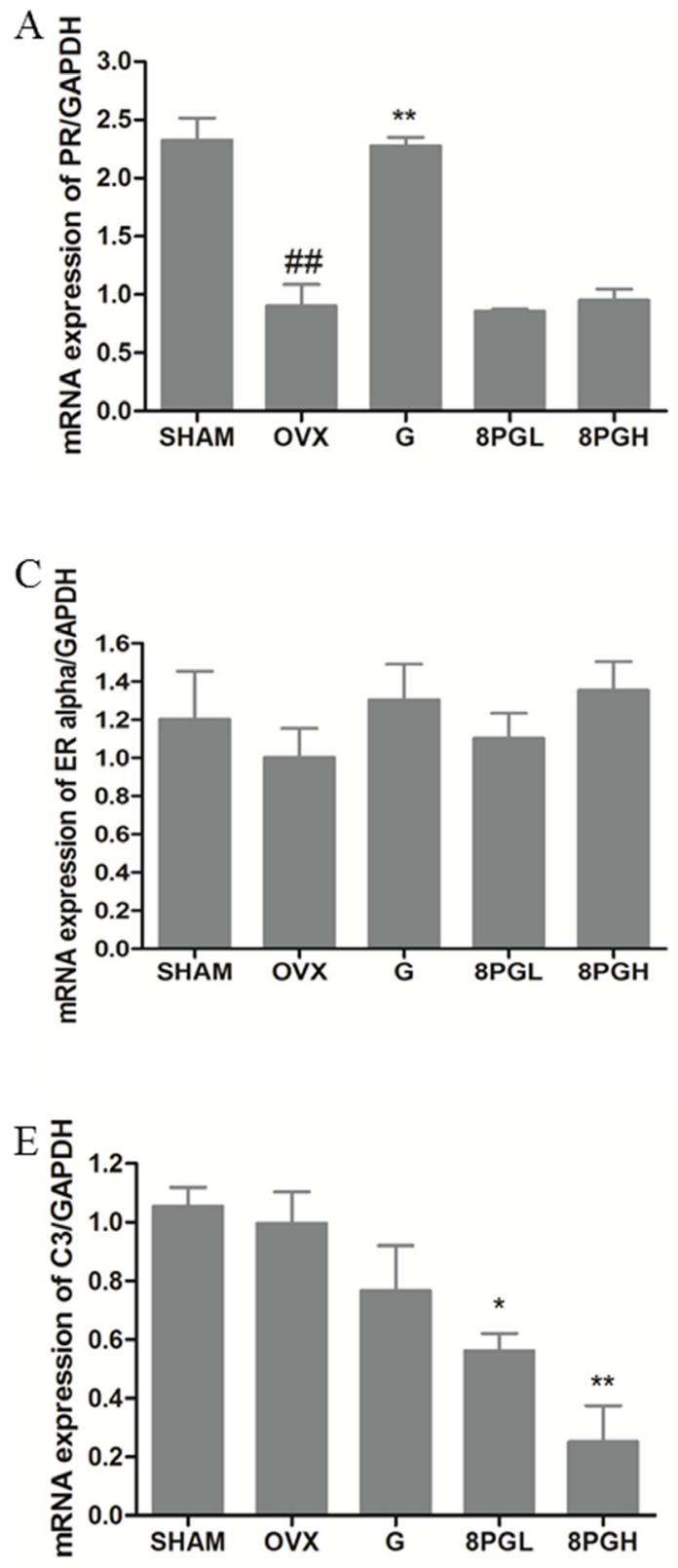

elevation of urinary calcium excretion. 8PG significantly suppressed ovariectomy-induced increase in serum osteopontin levels, a bone resorption marker in mice [28, 29]. Micro-CT analysis indicated that $8 \mathrm{PG}$ treatment significantly improved trabecular bone mineral density and micro-architecture at femoral end and tibial head in OVX mice. The histomorphological staining and reconstructed 3-dimensional images consistently showed that 8PG improved trabecular bone network and increased trabecular bone mass at distal metaphysis of femur and proximal metaphysis of tibia as well as improved the histological structure of articular cartilage at tibial

$\mathrm{B}$

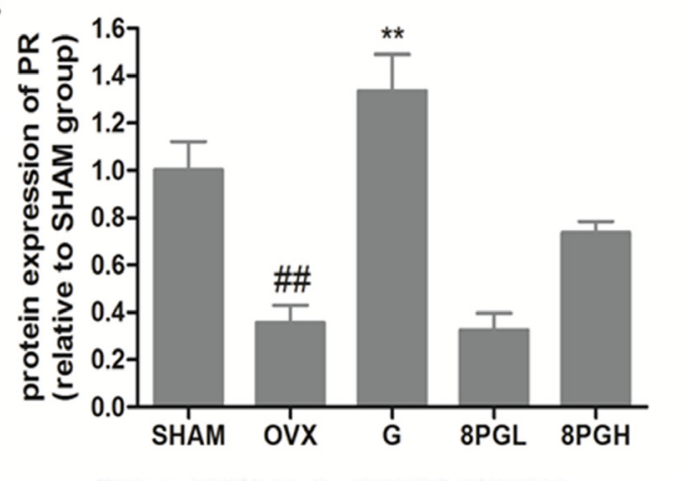

Sham OVX G SPGL SPGH
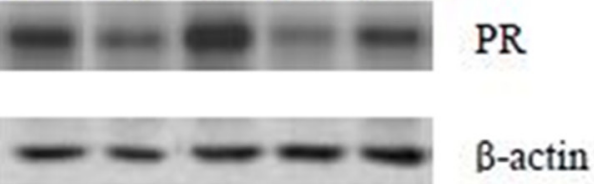

$\mathrm{D}$
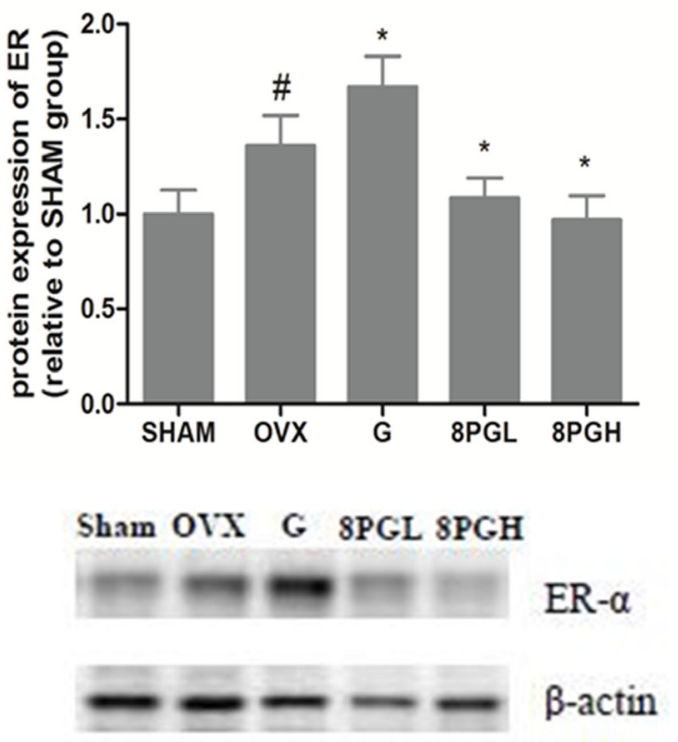

Figure 5: mRNA $(\mathbf{A}, \mathbf{C})$ and protein $(\mathbf{B}, \mathbf{D})$ expression of progesterone receptor $(\mathrm{PR}, \mathrm{A} \& \mathrm{~B})$ and estrogen receptor-alpha $(\mathrm{ER}-\alpha, \mathrm{C} \& \mathrm{D})$ as well as complement component 3 (C3) mRNA expression (E) in uterus of Sham mice and OVX mice treated with vehicle (OVX), genistein (G) or low (8PGL) or high $(8 \mathrm{PGH})$ dose of 8-prenylgenistein for 7 weeks. Values were expressed as means \pm SEM, $n=10 .{ }^{\#} P<0.05$, ${ }^{\#} P$ $<0.01$, vs. Sham group; ${ }^{*} P<0.05,{ }^{* *} P<0.01$, vs. OVX group. 
epiphysis. These results fully showed that 8 PG was effective in repressing the bone deteriorations induced by estrogen deficiency in OVX mice.

The responses of mRNA expression of genes involved in bone metabolism in OVX mice were studied in the present study in an attempt to characterize the differential actions of 8PG and genistein on bone. Our results clearly showed that the expression of genes involved in bone formation (ALP, OCN, COL) and gene involved in bone resorption ( $\mathrm{CtsK}$ ) in femur were significantly induced in OVX mice, a typical feature of high bone turnover associated with estrogen deficiency. Treatment of OVX mice with genistein significantly down-regulated the mRNA expression of ALP and OCN and reduced the ratio of RANKL/OPG (a marker for osteoclastogenesis) expression [30]. Similar results were reported by others that genistein reduced ALP activity and the expression of COL and OCN in human bone marrow mesenchymal stem cells [31] and suppressed the ratio of RANKL/OPG expression in bone of OVX mice [32]. Most importantly, our results showed that $8 \mathrm{PG}$ at both doses not only suppressed the expression of genes involved in bone formation (ALP, OCN) and osteoclastogenesis (RANKL/OPG), but also suppressed the expression of gene involved in bone resorption ( $\mathrm{CtsK}$ ) in OVX mice. Indeed, the suppression in Ctsk mRNA expression by $8 \mathrm{PG}$ was associated with the suppression of bone resorption marker in OVX mice, suggesting that 8PG might exert inhibitory actions on the process of bone resorption. Thus, our results clearly indicated that $8 \mathrm{PG}$ and genistein exerted differential actions on bone and that the suppression of the process of bone resorption by $8 \mathrm{PG}$ might account for its potent actions in protecting against rapid bone turnover induced by estrogen deficiency in mice.

One of the major concerns regarding the use of phytoestrogens, like genistein, was the undesirable effect in other reproductive organs $[7,8]$. To evaluate if $8 \mathrm{PG}$ exerted estrogenic effects in the reproductive tissues, the uterotrophic responses in OVX mice fed genistein and $8 \mathrm{PG}$ were compared. Treatment with genistein for 7

\section{A}

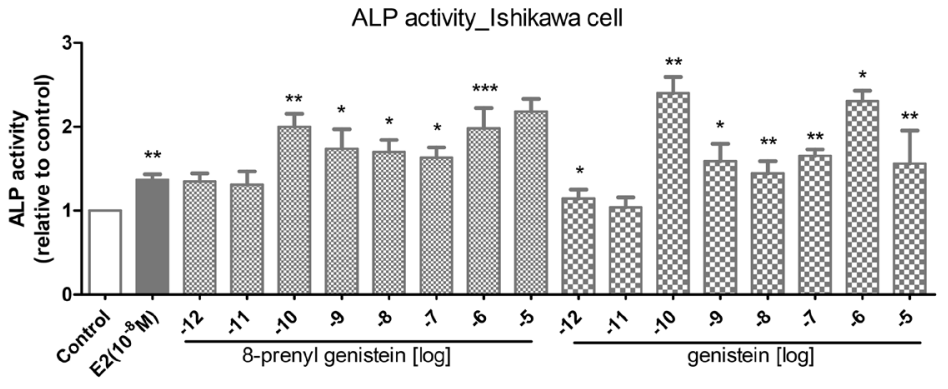

C

B
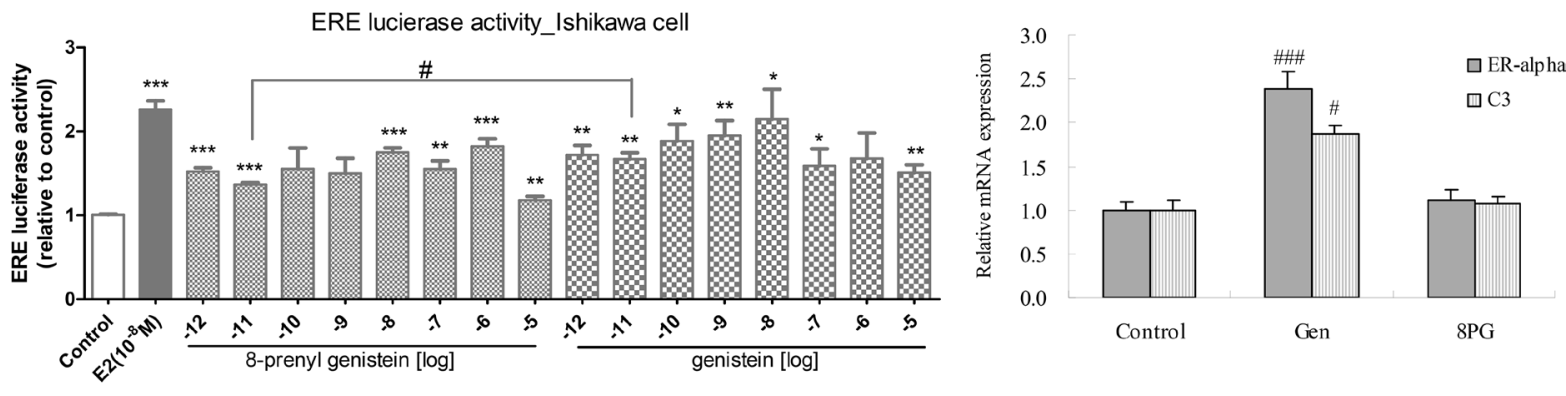

$\mathbf{D}$
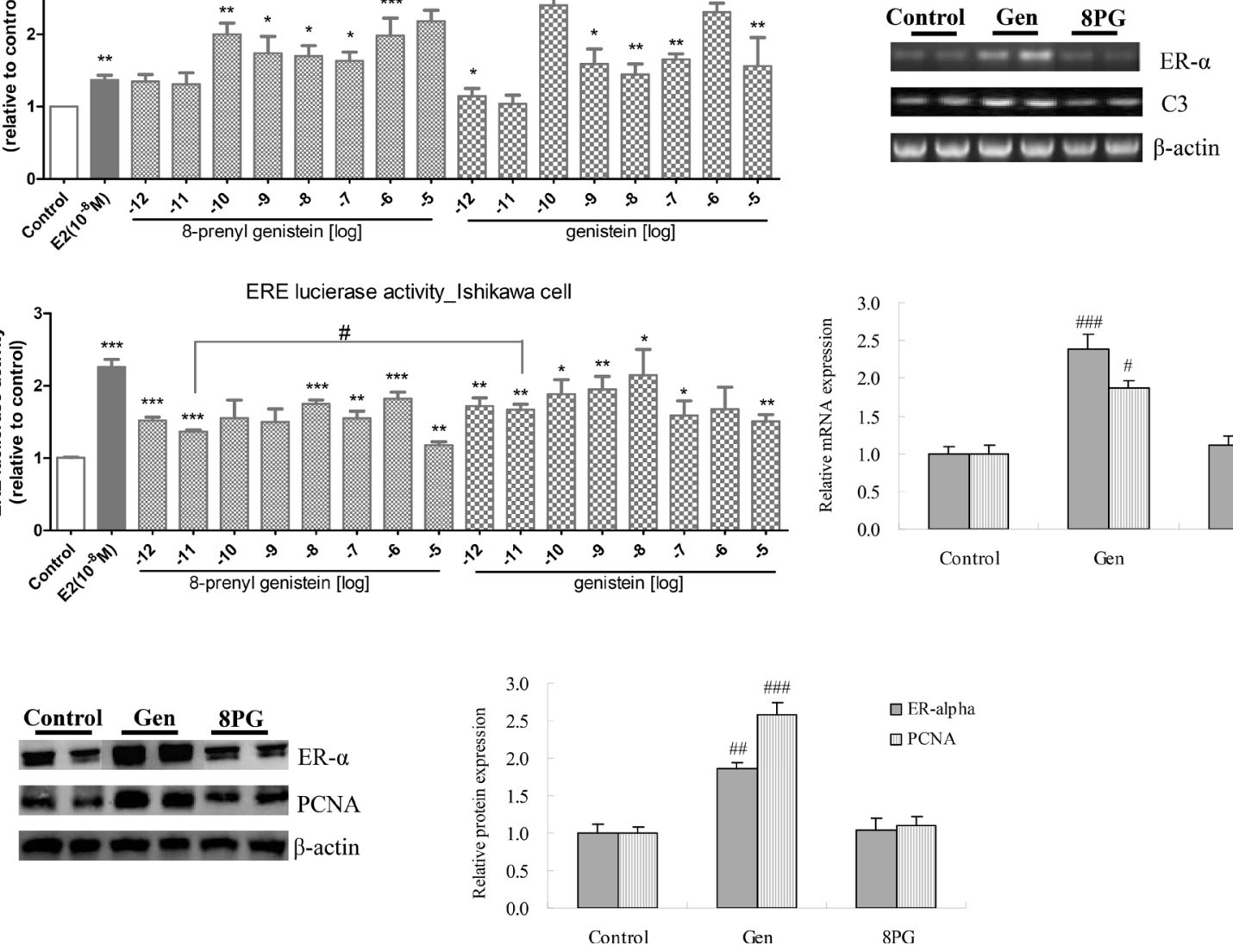

Control

Gen

8PG

Figure 6: Alkaline phosphatase activity (ALP, A), estrogen response element (ERE)-dependent transcriptional activity (B), mRNA expression of ER- $\alpha$ and $\mathrm{C} 3(\mathbf{C})$ as well as protein expression of ER- $\alpha$ and proliferating cell nuclear antigen (PCNA) (D) in human endometrial Ishikawa cell. ALP and ERE activities were measured in Ishikawa cells upon to the treatment with vehicle (Control), 17- $\beta$ estradiol (E2, $10^{-8} \mathrm{M}$ ), and 8-prenylgenistein and genistein at the concentration from $10^{-12} \mathrm{M}$ to $10^{-5} \mathrm{M}$. Molecular expression was detected in Ishikawa cells treated with vehicle (Control), genistein $\left(\mathrm{Gen}, 10^{-6} \mathrm{M}\right)$ and 8 -prenylgenistein $\left(8 \mathrm{PG}, 10^{-6} \mathrm{M}\right)$ for $48 \mathrm{~h}$. Values were expressed as means \pm SEM. ${ }^{*} P<0.05,{ }^{* *} P<0.01,{ }^{* * *} P<0.001$, vs. Control. ${ }^{\#} P<0.05,{ }^{\# \#} P<0.01,{ }^{\# \#} P<0.001$, vs. Control. 
weeks markedly increased the uterus index in OVX mice. Moreover, genistein significantly increased PR (a gene regulated by estrogen) mRNA and protein expression as well as ER $\alpha$ protein expression in uterus in OVX mice. In contrast, 8PG at both low and high dose did not increase uterus index nor increase PR mRNA and protein expression in uterus in OVX mice. Furthermore, 8PG reduced both $\mathrm{ER} \alpha$ protein expression and $\mathrm{C} 3$ (another estrogen-sensitive gene) mRNA expression in uterus in OVX mice. Such antagonism of estrogenic effects has also been reported for dihydrotestosterone (DHT), in which ER $\alpha$ expression in the endometrial stroma in OVX pigs was shown to be down-regulated by DHT [33]. These results clearly indicated that the effects of $8 \mathrm{PG}$ and genistein in uterus of OVX mice were different.

To further evaluate their potential estrogenic activities in human endometrial cells [34], their abilities to induce the activity of ALP and expression of PCNA, $\mathrm{C} 3$ and ER- $\alpha$ in Ishikawa cell were studied. PCNA is usually used as a biochemical marker for evaluating the proliferation of endometrial cancer cells [35], and C3 is one of the estrogen-responsive genes [36]. PCNA expression was induced by estrogen in breast cancer MCF-7 [37] and by genistein in a time- (at $48 \mathrm{~h}$ and afterward) and concentration-dependent manner (at 10(-8) $\mathrm{M}$ and above) in Ishikawa cells [38]. Our results clearly indicated that genistein $(1 \mu \mathrm{M})$, but not 8PG $(1 \mu \mathrm{M})$, induced ER- $\alpha$, PCNA and C3 expression in Ishikawa cells. Indeed, the observations were similar to those reported by Kretzschmar et al. [17] in which genistein was much more potent than $8 \mathrm{PG}$ in inducing estrogenic responses in yeast based assay. Indeed, the results of our in vitro study were in agreement with those in the in vivo study that $8 \mathrm{PG}$ and genistein exerted differential actions in endometrial cells and uterus. Our results indicated that $8 \mathrm{PG}$, with modification by prenylation in the chemical structure of genistein, diminished its side effects on reproductive tissues and exhibited tissue-selective estrogen-like effects on bone.

It is well known that in the classical pathway the actions of estrogen at cellular levels are mediated through
A

ER $\alpha$-binding assay

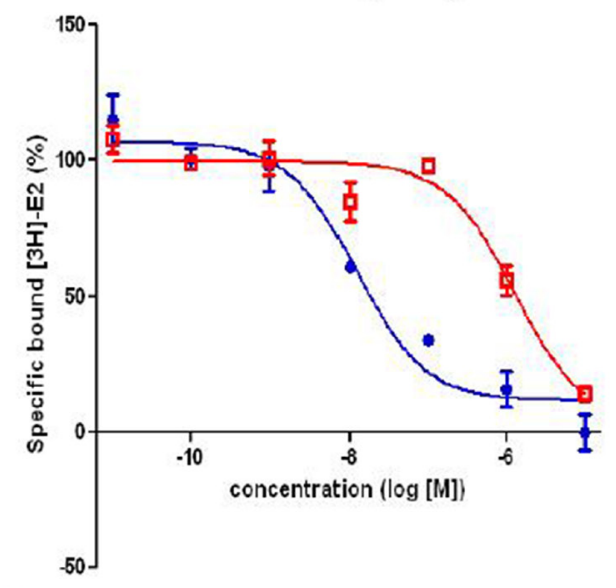

C

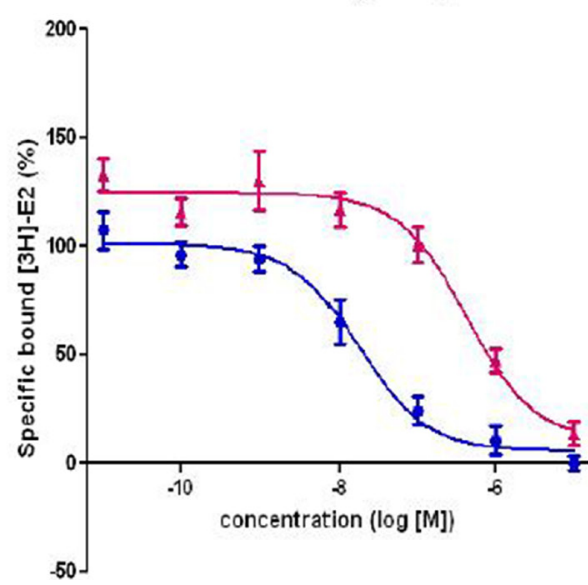

B

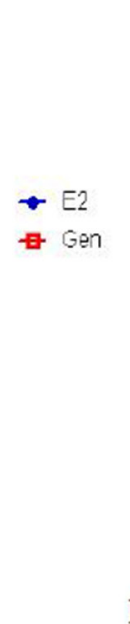

D

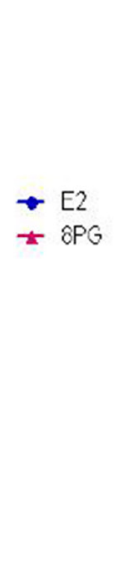

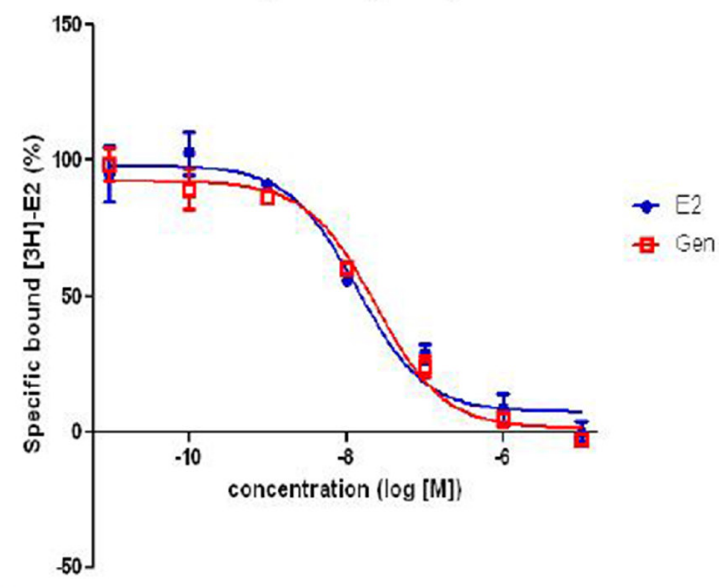

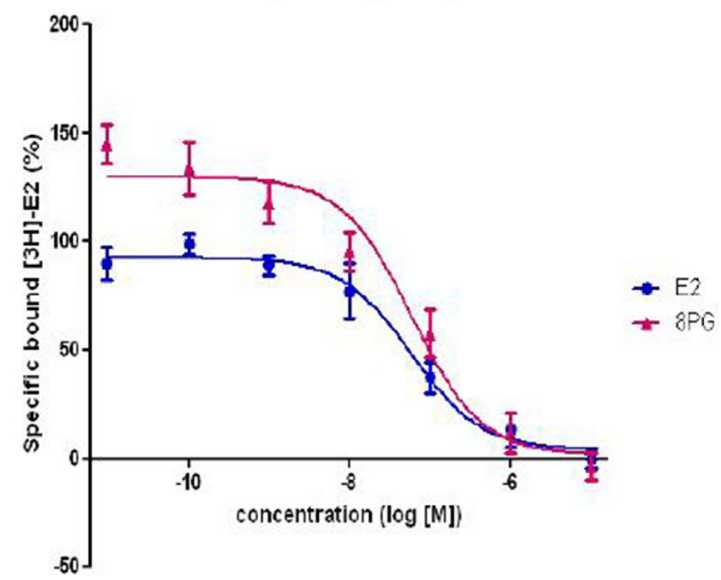

Figure 7: Competitive by genistein and 8-prenylgenistein for $\left[\mathrm{H}^{3}\right]-\mathrm{E}_{2}$ binding to recombinant human ER- $\alpha(\mathbf{A}, \mathbf{C})$ and ER- $\beta$ (B, D). Competition curves were obtained by adding increasing concentration of competitors to measure the displacement of bound radioligand. Results were expressed as percentage specific bound $\left[\mathrm{H}^{3}\right]-\mathrm{E}_{2}$ and obtained from three independent experiment. E2, 17- $\beta$ estradiol; Gen, genistein; 8PG, 8-prenylgenistein. 
ERs, mainly include ER $\alpha$ and ER $\beta$, and subsequently alter gene transcription [39]. Moreover, ER $\alpha$ is reported to be the main subtype of ERs that is involved in key biological actions in bone [40, 41] and uterus [42, 43]. Our study demonstrated that the affinity of genistein and $8 \mathrm{PG}$ to $\mathrm{ER} \alpha$ was comparable and weaker than estrogens. Our results also showed that the abilities of $8 \mathrm{PG}$ and genistein to activate ERE-dependent transcriptional activities in human osteoscaroma MG63 cells and human endometrial Ishikawa cell, and to stimulate ALP activity, an estrogenic response marker, in Ishikawa cells and in MG63 cells were comparable at most of concentration tested. Thus, the differential actions of 8PG and genistein in bone and uterus were not likely due to the difference in ER $\alpha$ binding affinity nor their abilities to induce ERE-dependent transcriptional or ALP activities in these tissues.

Interestingly, it appeared that the decrease in ER $\alpha$ expression in uterus might account for the decrease in uterotrophic responses (uterus index and C3 expression) in 8PG-treated OVX mice. Whereas, the decreased expression of ER $\alpha$ in bone tissue by $8 \mathrm{PG}$ may not account for its observed bone protective effects in OVX mice, as a decrease in estrogenic effects in bone means a decrease in anabolic effects on bone and an increase in bone resorption. Thus, our study suggested that other non-ER $\alpha$ dependent pathways, like Wnt/ $\beta$-catenin signaling and BMP signaling, might be involved in protective effects of $8 \mathrm{PG}$ on bone.

The key characteristics of 8PG in comparison to genistein were summarized as shown in Table 3 . In conclusion, the present study revealed the osteoprotective effects of 8-prenylgenistein without uterotrophic action in OVX mice. The tissue selective effect of 8PG may, at least partially, be accounted for its modulatory effects on ER $\alpha$ expression in bone and uterus. Recent research studies indicated that the actions of estrogen can also be mediated by rapid signaling events that involved transmembrane ER
A

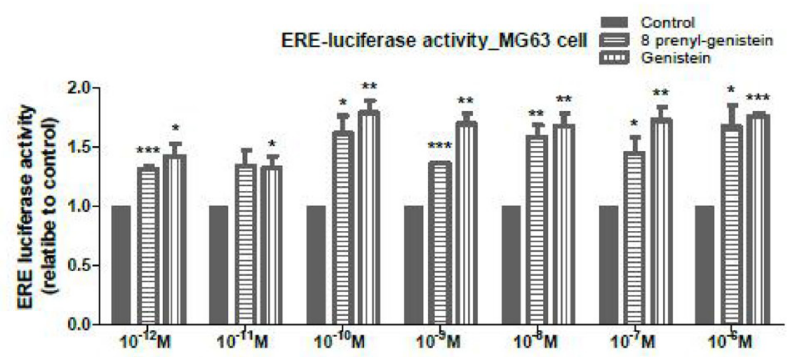

B

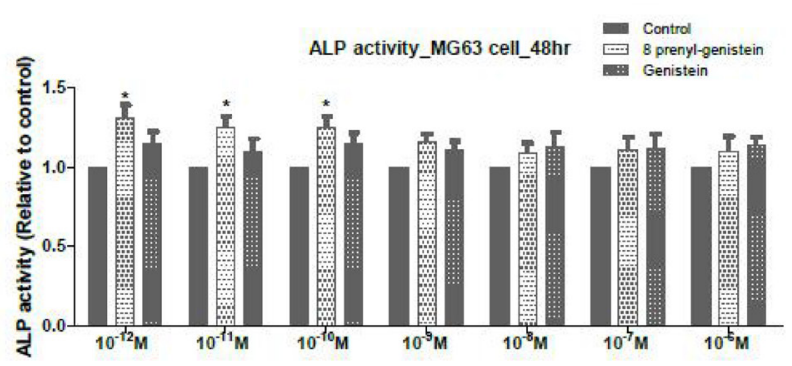

C
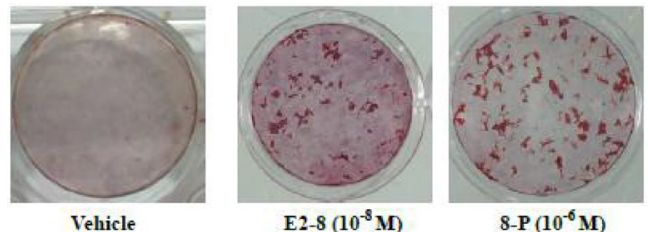
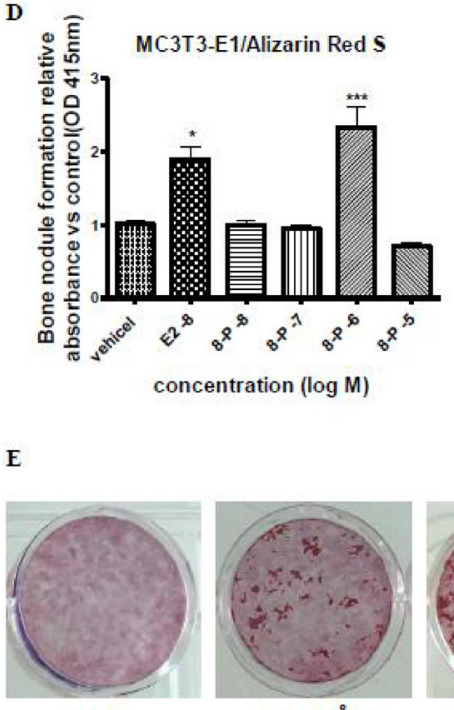

Vehicle

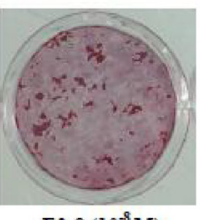

E2-8 $\left(10^{-8} \mathbf{M}\right)$

$\mathbf{F}$

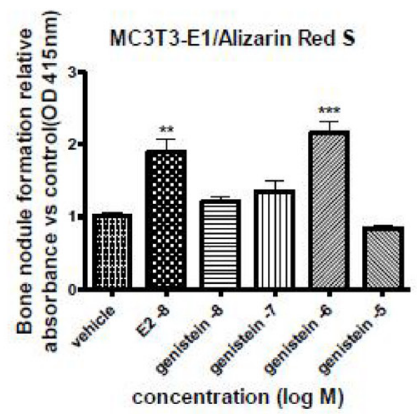

Figure 8: Estrogen response element (ERE)-dependent luciferase activity and alkaline phosphatase (ALP) activity of MG63 cells and bone nodule formation in murine osteoblastic MC3T3-E1 cells. Activities of ERE-luciferase (A) and ALP (B) were measured in MG63 cells after treatment with genistein and 8-prenylgenistein at the concentration from $10^{-12} \mathrm{M}$ to $10^{-6} \mathrm{M}$ for $24 \mathrm{~h}$ and $48 \mathrm{~h}$, respectively. Bone nodule formation by alizarin red staining was performed in MC3T3-E1 cells treated with vehicle, 17- $\beta$ estradiol $\left(\mathrm{E} 2,10^{-8} \mathrm{M}\right)$ and 8 -prenylgenistein $(\mathbf{C}, \mathbf{D})$ and genistein $(\mathbf{E}, \mathbf{F})$ at the concentration from $10^{-8} \mathrm{M}$ to $10^{-5} \mathrm{M}$ for 21 days. Data were expressed as mean \pm SEM. ${ }^{*} P<0.05,{ }^{* *} P<0.01,{ }^{* * *} P<0.001$, vs. Vehicle (Control) group. 
Table 3: Differential actions of genistein and 8-prenylgenistein on bone and uterus in ovariectomized mice and human endometrial Ishikawa cell

Genistein 8-prenylgenistein

\begin{tabular}{|c|c|c|}
\hline \multicolumn{3}{|l|}{ Biochemical markers } \\
\hline Serum $\mathrm{Ca}$ & & \\
\hline Urinary $\mathrm{Ca}$ & No change & $\uparrow$ \\
\hline Bone resorption marker & No change & $\downarrow$ \\
\hline $\begin{array}{l}\text { Bone resorption marker } \\
\text { (serum OPN) }\end{array}$ & No change & $\downarrow$ \\
\hline Bone properties & & \\
\hline Tibial head & & \\
\hline BMD & No change & $\uparrow$ \\
\hline Tb.Th & No change & $\uparrow$ \\
\hline DA & No change & $\downarrow$ \\
\hline Tb.Sp & No change & $\downarrow$ \\
\hline Femoral end & & \\
\hline BMD & $\uparrow$ & $\uparrow$ \\
\hline $\mathrm{BV} / \mathrm{TV}$ & $\uparrow$ & $\uparrow$ \\
\hline Tb.N & $\uparrow$ & $\uparrow$ \\
\hline Tb.Th & No change & $\uparrow$ \\
\hline Tb.Sp & $\downarrow$ & $\downarrow$ \\
\hline Uterus response & & \\
\hline Uterus index & $\uparrow$ & \\
\hline PR & $\uparrow$ & No change \\
\hline ER- $\alpha$ & $\uparrow$ & No change \\
\hline $\mathrm{C} 3$ & No change & $\downarrow$ \\
\hline Ishikawa cell & & $\downarrow$ \\
\hline ER- $\alpha$ & & No change \\
\hline PCNA & & No change \\
\hline $\mathrm{C} 3$ & & No change \\
\hline Binding affinities (RBA) & & \\
\hline ER- $\alpha$ & $0.99 \%$ & $4.31 \%$ \\
\hline ER- $\beta$ & $58.1 \%$ & $99.6 \%$ \\
\hline
\end{tabular}

$\mathrm{BMD}$, bone mineral density; BV/TV, bone volume over total volume; $\mathrm{C} 3$, complement component 3; Ca, calcium; DA, degree of anisotropy; ER- $\alpha$, estrogen receptor alpha; ER- $\beta$, estrogen receptor beta; OPN, osteopontin; PCNA, proliferating cell nuclear antigen; PR, progesterone receptor; RBA, relative binding affinity; Tb.N, trabecular bone number; $\mathrm{Tb} . \mathrm{Sp}$, trabecular bone separation; $\mathrm{Tb}$.Th, trabecular bone thickness.

[44]. Future study will be needed to delineate the other mechanisms, like nongenomic rapid signaling pathway and non-ER $\alpha$ dependent pathway, by which 8-prenylation achieves in vivo tissue selectivity.

\section{MATERIALS AND METHODS}

\section{Compounds}

Genistein was obtained from Sigma, and 8-prenylgenistein (8PG) was synthesized analogously starting from genistein (Changzhou University, Jiangsu, China). The purity of the used compounds was assessed to be $>99 \%$ (gas chromatography and high-performance liquid chromatography).

\section{Animals study design}

Three-month-old female C57BL/6J mice (The Chinese University of Hong Kong) were housed at the Centralized Animal Facility of the Hong Kong Polytechnic University with alternating $12 \mathrm{~h}$ periods of light and darkness, a constant temperature of $23 \pm 1^{\circ} \mathrm{C}$, and humidity of $55 \pm 5 \%$ upon arrival. The mice were acclimated for 1 month during which they were allowed free access to deionized distilled water and phytoestrogenfree diet (D00031602, Research Diet Inc, New Brunswick, NJ, USA). The latter was used as the control diet in this study and was prepared according to the AIN-93M formulation where corn oil was used instead of soybean oil. Soy oil was substituted by corn oil as a fat source in 
order to prevent any additional components of soy from being added to the diets. The mice were either dorsal ovariectomized (OVX) or sham-operated (Sham) under light ether anesthesia. Starting from post-surgery, the mice were divided into five groups: Sham-operated mice with control diet (Sham, $n=10$ ), OVX mice with control diet (OVX, $n=10$ ), OVX mice with genistein (D13052408, $600 \mathrm{mg} / \mathrm{kg}$ diet, $n=10$ ) or low dose (D13052402, 310 $\mathrm{mg} / \mathrm{kg}$ diet, $n=10$, 8PG-L) or high dose (D13052402, $620 \mathrm{mg} / \mathrm{kg}$ diet, $n=10,8 \mathrm{PG}-\mathrm{H}$ ) of 8-prenylgenistein. The diets were pelleted by dry extrusion and color-coded. The nutritional composition of different diets was shown in Supplementary File (Supplementary Table 1). All mice in each group were individually caged and pair-fed with approximately $5 \mathrm{~g}$ /day of the respective diet which was completely consumed by each animal. After 7 weeks of treatment, urine was collected by using metabolic cage. All mice were killed by cardiac exsanguination and then serum was prepared and stored at $-80^{\circ} \mathrm{C}$ for further biochemical analyses. The uterus, the bilateral tibias and femurs were aseptically removed and stored. All procedures were reviewed and approved by the Animal Ethics Committee of The Hong Kong Polytechnic University (approved No: 12/35).

\section{Chemistries in serum and urine}

Calcium ( $\mathrm{Ca}$ ) and phosphorus $(\mathrm{P})$ concentrations in serum and urine were measured by standard colorimetric methods. The content of osteocalcin (Immutopics, San Clemente, USA) and osteopontin (ALPCO, Salem, USA) in serum were assayed by using commercial ELISA kits.

\section{Micro-computed tomography (Micro-CT) analysis}

The proximal metaphysis of tibia and the distal end of femur were scanned with a high-resolution micro viva CT 40 system (Scanco Medical, Bassersdorf, Switzerland). Trabecular bone was determined by a fixed threshold. The scans resulted in reconstructed 3-dimensional (3-D) data sets with $\mu \mathrm{CT}$ Evaluation Program (V5.0A). After images were captured, 100 slices were established as the volume of interest. Trabecular bone was separated from cortical bone by free drawing regions of interests using the software provided with the scanner. Morphologic measurements of the metaphyseal trabecular bone for the 100 slices were performed to obtain 3-D images and the quantitative parameters as the following: (1) the mean bone mineral density of total volume (BMD/TV); (2) connectivity density (Conn.D); (3) bone volume (BV)/TV; (4) the geometric degree of anisotropy (DA); (5) trabecular bone number (Tb.N); (6) trabecular bone separation (Tb.Sp); (7) trabecular bone thickness (Tb.Th).

\section{Histological and immunohistochemical staining on trabecular bone}

The tibias and femurs were fixed, decalcified, and embedded in paraffin by standard histological procedures. Serial sections of $3 \mu \mathrm{m}$ were cut. Safranin O (Sigma-Aldrich) staining was performed, combining with fast green and counter stain by hematoxylin. Additionally, the alcian blue/hematoxylin \& orange G staining was performed on articular cartilage of tibial head. The protein expression of estrogen receptor-alpha $($ ER $-\alpha)$ at distal metaphysis of femur was detected by immunohistochemical staining. Stained slides were visualized under microscope.

\section{RT-PCR and quantitative RT-PCR}

RNA from the distal one third of the whole femur of each animal was protected from degradation by liquid nitrogen when being grinded in a mortar. Bone powder was put in an eppendorf tube filled with TRIzol reagent; Uterus was thawed in TRIzol reagent and homogenized. Total tissue RNAs was isolated according to the TRIzol manufacturer's protocol (Invitrogen, Carlsbad, California, USA). Synthesis of cDNAs was performed by reverse transcription reactions using moloney murine leukemia virus reverse transcriptase (Invitrogen, Carlsbad, California, USA). The first strand cDNAs served as the template for the regular PCR performed using a DNA Engine (ABI). Real-time RT-PCR was performed with the Applied Biosystems 7900 Real Time PCR System using a SYBR green PCR reagent kit (Applied Biosystems, Foster City, CA). Glyceraldehyde-3-phosphate dehydrogenase $(\mathrm{GAPDH})$ as an internal control was used to normalize the data to determine the relative expression of the target genes, including osteoprotegerin (OPG), receptor activator of nuclear factor kappa-B ligand (RANKL), ER$\alpha$, G protein-coupled estrogen receptor (GPER), alkaline phosphatase (ALP), type I collagen (COL), osteocalcin (OCN), cathepsin $\mathrm{K}$ (CtsK), progesterone receptor (PR), complement component 3 (C3). The PCR primers used in this study were shown in Supplementary File (Supplementary Table 2).

\section{Immunoblotting}

Uterus was thawed in Laemmli buffer (Boston Bioproducts, Worcester, MA, USA) and homogenized for protein isolation. The cell proteins were also extracted in Laemmli buffer. Protein samples were separated on SDSPAGE gel, transferred to PVDF membranes (Whatman). After saturation with $5 \%(\mathrm{w} / \mathrm{v})$ nonfat dry milk in TBS and $0.1 \%(\mathrm{w} / \mathrm{v})$ Tween $20(\mathrm{TBST})$, the membranes were incubated with rabbit polyclonal IgG ER- $\alpha$, PR or proliferating cell nuclear antigen (PCNA) and followed by incubation with goat anti-rabbit conjugated with horseradish 
peroxidase. The antigen-antibody complexes were then detected with enhanced chemiluminescence (ECL) reagent and visualized by the Lumi-Imager using Lumi-Analyst version 3.10 software (Roche, Mannheim, Germany).

\section{Human endometrial Ishikawa cell}

An immortalized human uterine endometrial adenocarcinoma cell line (Ishikawa) was obtained from ATCC (American Type Culture Collection, Manassas, USA). Cells were grown in a standard tissue culture incubator at $37^{\circ} \mathrm{C}$, with $95 \%$ humidity and $5 \%$ carbon dioxide. Ishikawa cells were maintained in DMEM/F12 (Hyclone, USA) supplemented with 10\% FBS (Gibico, USA). Cells were seeded in a 6-well plate, and twentyfour hours prior to cell treatment, media were changed to phenol red-free DMEM/F12 containing 5\% charcoalstripped heat-inactivated FBS. Cells were treated with genistein $\left(10^{-6} \mathrm{M}\right)$ or 8-prenylgenistein $\left(10^{-6} \mathrm{M}\right)$ dissolved in ethyl alcohol absolute (EtOH). EtOH diluted in medium was used as blank control. Upon treatment for $48 \mathrm{~h}$, RNA was isolated by TRIzol and protein was obtained by RIPA lysis buffer supplemented with proteinase inhibitors cocktail (Roche, Mannheim, Germany). RT-PCR and immunoblotting for $\mathrm{ER}-\alpha, \mathrm{C} 3$ and proliferating cell nuclear antigen (PCNA) were further performed.

\section{Binding affinity assay with purified $\mathrm{ER} \alpha$ and ERß}

96-well microtiter filter plates (Millipore, USA) were used in the assay. Each compound was diluted with 1:1 dimethylsulf- oxide assay buffer (50 mM Tris, $10 \%$ glycerol, $\mathrm{pH} 8.0,0.3 \mathrm{mg} / \mathrm{ml}$ ovalbumin, $0.01 \mathrm{M}$ mercaptoethanol) to seven concentrations from $7 \times 10^{-11}$ $\mathrm{M}$ to $7 \times 10^{-5} \mathrm{M} .10 \mu \mathrm{l}$ compound dilutions, $10 \mu \mathrm{l}^{3}[\mathrm{H}]$ E2 $\left(7 \times 10^{-8} \mathrm{M}\right)$ and $50 \mu \mathrm{l}$ recombinant ER protein $(1.0$ $\left.\times 10^{-9} \mathrm{M}\right)($ PanVera/Invitrogen Corp, Carlsbad, USA) were loaded into each well. The plates were shaken in an orbital shaker for $5 \mathrm{~min}$ and incubated overnight (18$24 \mathrm{~h}$ ) on ice. HAP slurry (Bio- Rad Pacific Ltd., USA) was added and incubated for $15 \mathrm{~min}$ at $0^{\circ} \mathrm{C}$ to capture the protein. The trapped proteins were washed twice with ice cold HAP washing buffer and re-suspended in HAP washing buffer. Portions of the solution were mixed with scintillation fluid (Fisher Scientific, USA) and subjected to measurement by a liquid scintillation counter (Beckman LS6500 Scintillation Counter, USA). The radioactivity of each sample was expressed as disintegration per minute $(\mathrm{dpm})$. The binding of ${ }^{3}[\mathrm{H}]$ E2 to ER in the presence of competitor was determined by subtracting the non-specific binding and expressed as percentage of total binding without competitor. The relative binding affinities $(\mathrm{RBA})$ were calculated by $\left(\mathrm{IC}_{50}\right.$ $17 \beta$-estradiol $/ \mathrm{IC}_{50}$ compound) $\times 100$.

\section{Alkaline phosphatase (ALP) activity}

Ishikawa cells or the human osteosarcoma cells (MG63 ) were seeded and cultured in 24-well plate at the density of $5 \times 10^{4} /$ well. 24 hours later, the medium was changed to phenol-red free MEM containing 2\% charcoal stripped FBS (cs-FBS) for another $24 \mathrm{~h}$ followed by treatment with $8 \mathrm{PG}$ or genistein at different concentrations for $48 \mathrm{~h}$. Cells were rinsed by PBS for three times and lysed with $100 \mu \mathrm{l}$ of $1 \times$ passive lysis buffer (PLB, Promega) per well overnight at $-20^{\circ} \mathrm{C}$. ALP activity of each well was measured by LabAssayTM ALP kit (Wako) according to the manufacturer's instruction. Protein concentration of treated cells was measured by Bradford assay to normalize the ALP activity.

\section{Estrogen response element luciferase activity}

MG63 cells and Ishikawa cells were seeded in 24 -well plate at the density of $3 \times 10^{4} /$ well. Cells were transfected with $0.4 \mu \mathrm{g}$ pERE-luc and $0.01 \mathrm{mg}$ pRLTK with lipofectamine 2000 and incubated for $6 \mathrm{~h}$. The cells were treated with vehicle, various concentrations of 8-prenylgenistein and genistein for $24 \mathrm{~h}$. Firefly and Renilla Luciferase activities were measured sequentially with Dual Luciferase Assay reagents.

\section{Bone nodule formation of murine osteoblastic MC3T3-E1 cells}

MC3T3-E1 cells were seeded in 12-well plate at a density of $2 \times 10^{4}$ cells/well. The medium was changed to differentiation medium ( $\alpha$-MEM with $10 \%$ FBS and $25 \mu \mathrm{g} / \mathrm{ml}$ of ascorbic acid and $10 \mu \mathrm{mM}$ of $\beta$-glycerophosphate) with $10^{-8} \mathrm{M}$ E2 (positive control), vehicle $(1 \%$ ethanol) and different concentrations of 8PG and genistein $\left(10^{-8} \mathrm{M}\right.$ to $\left.10^{-5} \mathrm{M}\right)$. The medium was changed every $2 \sim 3$ days. After 21 days, the cells were rinsed with PBS for two times and fixed in $4 \%$ formaldehyde. Cells were then stained with $1 \%$ Alizarin Red for 10 minutes and captured under light microscope by using camera (Olympus, Japan). In order to quantify the bone nodule formation, $0.5 \mathrm{M} \mathrm{HCl}$ and 5\% SDS were added to the stained wells, which were shook for 30 minutes to completely dissolve cells. The optical density was measured at $415 \mathrm{~nm}$ by spectrophotometric plate reader (Bio-Rad model 550, Japan).

\section{Statistical analysis}

The data from these experiments were reported as mean \pm standard error of mean (SEM) for each group. All statistical analyses were performed using PRISM version 4.0 (GraphPad). Inter-group differences were analyzed by one-way ANOVA, and followed by Tukey's multiple comparison test as a post test to compare the group means 
if overall $P<0.05$. Differences with $P$ value of less than 0.05 were considered statistically significant.

\section{Author contributions}

Yan Z., Q.S., Y.W. and M.W. contributed to the study conception and design. L.Z., X.L., Yong Z., M.H., Z.Q., and D.Z. contributed to the acquisition of data or analysis and interpretation of data. K.M. contributed to reagents/ materials/analysis tools. Yan Z. wrote and M.W. revised the manuscript. All authors contributed in revising the manuscript and approved the final version to be submitted.

\section{CONFLICTS OF INTEREST}

All authors state that they have no conflicts of interest.

\section{FUNDING}

This work was supported by the Program of Innovative Research Team from Ministry of Science and Technology of P.R.China (2015RA4002), Innovative Research Team in University (PCSIRT, IRT1270), Natural Science Foundation of Shanghai (17ZR1430800), National Natural Science Foundation of China (81774329, 81603643), Shenzhen Basic Research Program [JCYJ20140819153305696, JCYJ20140819153305697], Shenzhen Knowledge Innovation Programme [JCYJ20151030164008764] and Longhua Medical Innovation Team Program (LYCX-01) as well as research support of the Hong Kong Polytechnic University (IBBAB).

\section{REFERENCES}

1. Coxam V. Symposium on "Diet and bone health" Phytooestrogens and bone health. Proc Nutr Soc. 2008; 67: 184-195.

2. Chen KI, Erh MH, Su NW, Liu WH, Chou CC, Cheng KC. Soyfoods and soybean products: from traditional use to modern applications. Appl Microbiol Biotechnol. 2012; 96:9-22.

3. Takagi A, Kano M, Kaga C. Possibility of breast cancer prevention: use of soy isoflavones and fermented soy beverage produced using probiotics. Int J Mol Sci. 2015; 16:10907-10920.

4. Zheng X, Lee SK, Chun OK. Soy isoflavones and osteoporotic bone loss: A review with an emphasis on modulation of bone remodeling. J Med Food. 2016; 19:1-14.

5. Baglia ML, Gu K, Zhang X, Zheng Y, Peng P, Cai H, Bao PP, Zheng W, Lu W, Shu XO. Soy isoflavone intake and bone mineral density in breast cancer survivors. Cancer Causes Control. 2015; 26:571-580.

6. Kaludjerovic J, Ward WE. Bone-specific gene expression patterns and whole bone tissue of female mice are programmed by early life exposure to soy isoflavones and folic acid. J Nutr Biochem. 2015; 26:1068-1076.

7. Al-Anazi AF, Qureshi VF, Javaid K, Qureshi S. Preventive effects of phytoestrogens against postmenopausal osteoporosis as compared to the available therapeutic choices: An overview. J Nat Sci Biol Med. 2011; 2:154-163.

8. Alekel DL, Genschel U, Koehler KJ, Hofmann H, Van Loan MD, Beer BS, Hanson LN, Peterson CT, Kurzer MS. Soy isoflavones for reducing bone loss study: effects of a 3-year trial on hormones, adverse events, and endometrial thickness in postmenopausal women. Menopause. 2015; 22:185-197.

9. Andres A, Moore MB, Linam LE, Casey PH, Cleves MA, Badger TM. Compared with feeding infants breast milk or cow-milk formula, soy formula feeding does not affect subsequent reproductive organ size at 5 years of age. J Nutr. $2015 ; 145: 871-875$.

10. Wang Y, Tan W, Li WZ, Li Y. A facile synthetic approach to prenylated flavanones: first total syntheses of $( \pm)$-bonannione A and $( \pm)$-sophoraflavanone A. J Nat Prod. 2001; 64:196-199.

11. Chen X, Mukwaya E, Wong MS, Zhang Y. A systematic review on biological activities of prenylated flavonoids. Pharm Biol. 2014; 52:655-660.

12. Sun H, Li Y, Zhang X, Lei Y, Ding W, Zhao X, Wang H, Song X, Yao Q, Zhang Y, Ma Y, Wang R, Zhu T, et al. Synthesis, $\alpha$-glucosidase inhibitory and molecular docking studies of prenylated and geranylated flavones, isoflavones and chalcones. Bioorg Med Chem Lett. 2015; 25:4567-4571.

13. Wang ZQ, Weber N, Lou YJ, Proksch P. Prenylflavonoids as nonsteroidal phytoestrogens and related structure-activity relationships. ChemMedChem. 2006; 1:482-488.

14. Simons R, Gruppen H, Bovee TF, Verbruggen MA, Vincken JP. Prenylated isoflavonoids from plants as selective estrogen receptor modulators (phytoSERMs). Food Funct. 2012; 3:810-27.

15. Luo D, Kang L, Ma Y, Chen H, Kuang H, Huang Q, He M, Peng W. Effects and mechanisms of 8-prenylnaringenin on osteoblast MC3T3-E1 and osteoclast-like cells RAW264.7. Food Sci Nutr. 2014; 2:341-350.

16. Paoletti T, Fallarini S, Gugliesi F, Minassi A, Appendino G, Lombardi G. Anti-inflammatory and vascularprotective properties of 8-prenylapigenin. Eur J Pharmacol. 2009; 620:120-130.

17. Kretzschmar G, Zierau O, Wober J, Tischer S, Metz P, Vollmer G. Prenylation has a compound specific effect on the estrogenicity of naringenin and genistein. J Steroid Biochem Mol Biol. 2010; 118:1-6.

18. Milligan S, Kalita J, Pocock V, Heyerick A, De Cooman L, Rong H, De Keukeleire D. Oestrogenic activity of the hop phyto-oestrogen, 8-prenylnaringenin. Reproduction. 2002; 123:235-242.

19. Ming LG, Chen KM, Xian CJ. Functions and action mechanisms of flavonoids genistein and icariin in regulating bone remodelling. J Cell Physiol. 2011; 112:916-923. 
20. Ming LG, Lv X, Ma XN, Ge BF, Zhen P, Song P, Zhou J, Ma HP, Xian CJ, Chen KM. The prenyl group contributes to activities of phytoestrogen 8-prenynaringenin in enhancing bone formation and inhibiting bone resorption in vitro. Endocrinology. 2013; 154:1202-1214.

21. Ming LG, Ge BF, Wang MG, Chen KM. Comparison between 8-prenylnarigenin and narigenin concerning their activities on promotion of rat bone marrow stromal cells' osteogenic differentiation in vitro. Cell Prolif. 2012; 45:508-515.

22. Zhang Y, Li XL, Yao XS, Wong MS. Osteogenic activities of genistein derivatives were influenced by the presence of prenyl group at ring A. Arch Pharm Res. 2008; 31:1534-1539.

23. Li XL, Wang NL, Wong MS, Yao S, Chen A. Four new isoflavonoids from the stem bark of Erythrina variegata. Chem Pharm Bull (Tokyo). 2006; 54:570-573.

24. Zhang Y, Li XL, Lai WP, Chen B, Chow HK, Wu CF, Wang NL, Yao XS, Wong MS. Anti-osteoporotic effect of Erythrina variegata L. in ovariectomized rats. J Ethnopharmacol. 2007; 109:165-169.

25. Zhang Y, Li Q, Li XL, Wan HY, Wong MS. Erythrina variegata extract exerts osteoprotective effects by suppression of the process of bone resorption. Br J Nutr. 2010; 104:965-971.

26. Shanle EK, Xu W. Endocrine disrupting chemicals targeting estrogen receptor signaling: identification and mechanisms of action. Chem Res Toxicol. 2011; 24:6-19.

27. Jiang Y, Gong P, Madak-Erdogan Z, Martin T, Jeyakumar M, Carlson K, Khan I, Smillie TJ, Chittiboyina AG, Rotte SC, Helferich WG, Katzenellenbogen JA, Katzenellenbogen BS. Mechanisms enforcing the estrogen receptor $\beta$ selectivity of botanical estrogens. FASEB J. 2013; 27:4406-4418.

28. Polat B, Halici Z, Cadirci E, Albayrak A, Karakus E, Bayir Y, Bilen H, Sahin A, Yuksel TN. The effect of alphalipoic acid in ovariectomy and inflammation-mediated osteoporosis on the skeletal status of rat bone. Eur J Pharmacol. 2013; 718:469-474.

29. Iwadate H, Kobayashi H, Kanno T, Asano T, Saito R, Sato S, Suzuki E, Watanabe H, Ohira H. Plasma osteopontin is correlated with bone resorption markers in rheumatoid arthritis patients. Int J Rheum Dis. 2014; 17:50-56.

30. Zhang Y, Dong XL, Leung PC, Wong MS. Differential mRNA expression profiles in proximal tibia of aged rats in response to ovariectomy and low-Ca diet. Bone. 2009; $44: 46-52$.

31. Zhang LY, Xue HG, Chen JY, Chai W, Ni M. Genistein induces adipogenic differentiation in human bone marrow mesenchymal stem cells and suppresses their osteogenic potential by upregulating PPAR $\gamma$. Exp Ther Med. 2016; 11:1853-1858.

32. Zhang Y, Li Q, Wan HY, Helferich WG, Wong MS. Genistein and a soy extract differentially affect three-dimensional bone parameters and bone-specific gene expression in ovariectomized mice. J Nutr. 2009; 139:2230-2236.
33. Cárdenas H, Pope WF. Attenuation of estrogenic effects by dihydrotestosterone in the pig uterus is associated with downregulation of the estrogen receptors. Biol Reprod. 2004; 70:297-302.

34. Naciff JM, Khambatta ZS, Carr GJ, Tiesman JP, Singleton DW, Khan SA, Daston GP. Dose- and time-dependent transcriptional response of Ishikawa cells exposed to genistein. Toxicol Sci. 2016; 151:71-87.

35. Dohi S, Ohno S, Ohno Y, Soma G, Kyo S, Inoue M. Correlation between WT1 expression and cell proliferation in endometrial cancer. Anticancer Res. 2009; 29:4887-4891.

36. Papke A, Kretzschmar G, Zierau O, Kaszkin-Bettag M, Vollmer G. Effects of the special extract ERr 731 from Rheum rhaponticum on estrogen-regulated targets in the uterotrophy model of ovariectomized rats. J Steroid Biochem Mol Biol. 2009; 117:176-184.

37. Xiang Y, Lu DL, Li JP, Yu CX, Zheng DL, Huang X, Wang ZY, Hu P, Liao XH, Zhang TC. Myocardin inhibits estrogen receptor alpha-mediated proliferation of human breast cancer MCF-7 cells via regulating MicroRNA expression. IUBMB Life. 2016; 68:477-487.

38. Kayisli UA, Aksu CA, Berkkanoglu M, Arici A. Estrogenicity of isoflavones on human endometrial stromal and glandular cells. J Clin Endocrinol Metab. 2002; 87:5539-5544.

39. Veprik A, Khanin M, Linnewiel-Hermoni K, Danilenko M, Levy J, Sharoni Y. Polyphenols, isothiocyanates, and carotenoid derivatives enhance estrogenic activity in bone cells but inhibit it in breast cancer cells. Am J Physiol Endocrinol Metab. 2012; 303:E815-824.

40. Lee SH, Oh KN, Han Y, Choi YH, Lee KY. Estrogen receptor $\alpha$ regulates Dlx3-mediated osteoblast differentiation. Mol Cells. 2016; 39:156-162.

41. Chow SK, Leung KS, Qin J, Guo A, Sun M, Qin L, Cheung WH. Mechanical stimulation enhanced estrogen receptor expression and callus formation in diaphyseal long bone fracture healing in ovariectomy-induced osteoporotic rats. Osteoporos Int. 2016; 27:2989-3000.

42. Lim SK, Won YJ, Lee HC, Huh KB, Park YS. A PCR analysis of ERalpha and ERbeta mRNA abundance in rats and the effect of ovariectomy. J Bone Miner Res. 1999; 14:1189-1196.

43. Li X, Song QS, Wang JY, Leng HJ, Chen ZQ, Liu ZJ, Dang GT, Song CL. Simvastatin induces estrogen receptor-alpha expression in bone, restores bone loss, and decreases ER $\alpha$ expression and uterine wet weight in ovariectomized rats. J Bone Miner Metab. 2011; 29:396-403.

44. Le Romancer M, Treilleux I, Bouchekioua-Bouzaghou K, Sentis S, Corbo L. Methylation, a key step for nongenomic estrogen signaling in breast tumors. Steroids. 2010; 75 : $560-564$. 